\title{
Comprehensive National Energy Strategy
}

National Energy Policy Plan

Pursuant to Section 801

of the Department of Energy Organization Act

Washington, D.C.

April 1998

PmatBUTON OF nMIS DOCUMEN IS UNLIMTED 


\section{Message from the Secretary of Energy}

I am pleased to convey the Department's Comprehensive National Energy Strategy, pursuant to Section 801 of the Department of Energy Organization Act. This Strategy is the result of an interaction among the Department of Energy, other Federal agencies, and the public at large through the hearing and comment process.

There are compelling reasons for a new and comprehensive energy strategy at this time. First, energy plays a vital role in our economy - accounting for over 7 percent of our gross domestic product, or about $\$ 2,000$ annually for every man, woman, and child in the United States. In addition, energy is big business. The global market for energy sup-

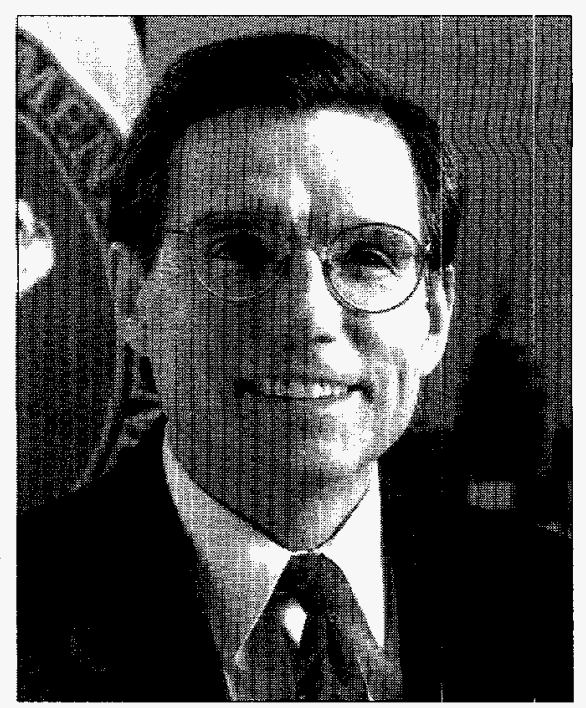
ply equipment alone in 1996 was over half a trillion dollars.

Second, our national security depends on affordable and abundant supplies of energy. Under every conceivable scenario projected by energy analysts, natural gas and oil will remain a central part of our Nation's energy future. As the world demand for oil grows, the United States does not want to rely on any particular region of the world for imported oil. Moreover, our own dependence on imported oil is expected to grow from 50 percent today to 60 percent by 2010 .

Third, we recognize that the environmental effects from production and use of energy are significant. On a local level, we know that fossil fuel use is associated with regional haze and smog. On a global scale, many experts believe that human activities associated with energy production and use have significantly altered the composition of atmospheric gasses.

Lastly, the U.S. economy still has ample opportunity to make further progress in the way we supply and use energy. Good public policy demands that we use our vital energy resources as wisely as possible. 


\section{DISCLAIMER}

Portions of this document may be illegible electronic image products. Images are produced from the best available original document. 
We are at a historic moment when we have the flexibility to develop our responses to the energy challenges we see. We are not facing an immediate crisis. Our economy is doing well. Energy supplies seem ample. The environment is steadily improving. Our Comprehensive National Energy Strategy is a forward-looking effort that seeks to address the major energy challenges facing the Nation and to provide the basis for guiding and directing future action. The Strategy is based on five common-sense goals:

- Improving the efficiency of our energy system - for example, by widely deploying new technologies to make more effective use of our energy resources.

- Ensuring against energy disruptions by reducing the threat of supply interruption and increasing the security and reliability of our energy infrastructure.

- Promoting energy production and use in ways that protect our health and environment.

- Expanding future energy choices through wise investments in basic science and new technologies.

- Cooperating internationally on energy issues to help develop the means to address global economic, security, and environmental concerns.

This Strategy is the beginning of what I believe is a journey toward energy security, economic expansion, and protection of our environment. We have constructed this Strategy so the American people can track and measure our progress as we develop and implement steps to achieve our goals.

I believe you will find this new energy strategy innovative and in the best interests of the American people. I welcome your support.

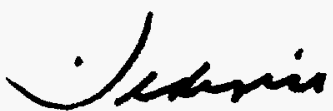

Federico F. Peña

Secretary of Energy

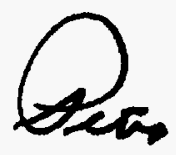


Foreword $\ldots \ldots \ldots \ldots \ldots \ldots \ldots \ldots \ldots \ldots \ldots \ldots \ldots \ldots \ldots \ldots \ldots$

The Strategy at a Glance $\ldots \ldots \ldots \ldots \ldots \ldots \ldots \ldots \ldots \ldots \ldots$ viii

Comprehensive National Energy Strategy $\ldots \ldots \ldots \ldots \ldots \ldots \ldots$

Energy - the Economy's Lifeblood $\ldots \ldots \ldots \ldots \ldots \ldots \ldots \ldots \ldots \ldots \ldots \ldots$

The U.S. Energy Landscape . . . . . . . . . . . . . . . . . . . 3

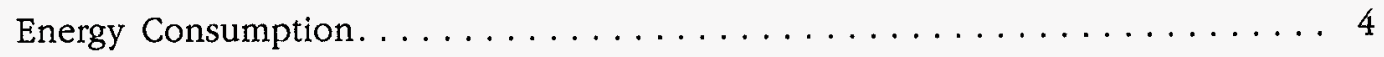

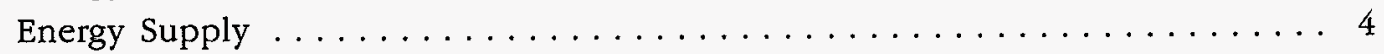

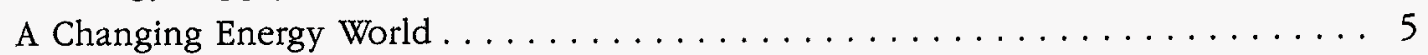

Global Economic Transformation and Energy Security .............. 5

Competition in the U.S. Electricity Market . . . . . . . . . . . . . 6

International Response to Climate Change . . . . . . . . . . . . . 6

Energy Technology: The Essential Basis for Progress . . . . . . . . . . . 8

Proposed National Energy Goals . . . . . . . . . . . . . . . . . . . 9

Goal I: Improve the Efficiency of the Energy System . . . . . . . . . . 10

Goal II: Ensure Against Energy Disruptions . . . . . . . . . . . . . 15

Goal III: Promote Energy Production and Use in Ways That Respect

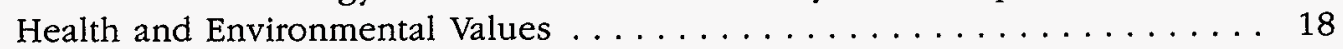

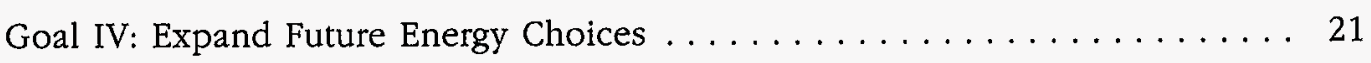

Goal V: Cooperate Internationally on Global Issues ............. 23

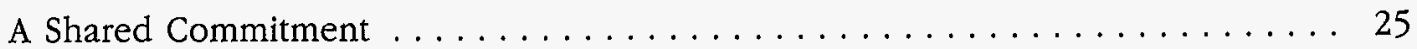

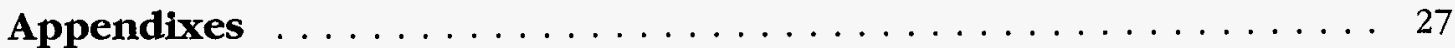

A. The Kyoto Protocol on Climate Change. . . . . . . . . . . . . . . . 29

B. The President's Climate Change Technology Initiative ............. 33

Summary of Public Comments $\ldots \ldots \ldots \ldots \ldots \ldots \ldots \ldots \ldots$ 

$\mathbf{W}$

hen the Department of Energy was created in 1977, the law required that a "National Energy Policy Plan" be regularly submitted to Congress. The President, the Department, the Congress, and the American people have all found this regular planning process useful, not only when energy prices have skyrocketed, as was the case when the first policy plan was due in 1979, but also in times like today, when energy supplies are abundant and affordable. Although there appears to be no energy crisis now, serious energy issues remain to be addressed to ensure that the Nation's current and future energy requirements can be met in a way that continues to grow the economy while improving protection of the environment and the health and safety of the American people.

This Comprehensive National Energy Strategy sets forth a set of five common sense goals for national energy policy [see box on next page]. These goals are further elaborated by a series of objectives and strategies to illustrate how these goals will be achieved.
Taken together, the goals, objectives, and strategies form a blueprint for the specific programs, projects, initiatives, investments, and other actions that will be developed and undertaken by the Federal Government, with significant emphasis on the importance of the scientific and technological advancements that will allow implementation of this Comprehensive National Energy Strategy. Moreover, the statutory requirement of regular submissions of national energy policy plans ensures that this framework can be modified to reflect evolving conditions, such as better knowledge of our surroundings, changes in energy markets, and advances in technology. This Strategy, then, should be thought of as a living document.

Finally, this plan benefited from the comments and suggestions of numerous individuals and organizations, both inside and outside of government. The Summary of Public Comments, located at the end of this document, describes the public participation process and summarizes the comments that were received. 


\section{The Strategy at a Glance}

Goal I. Improve the efficiency of the energy system - making more productive use of energy resources to enhance overall econiomic performance while protecting the environment and advancing national security.

Objective 1 Support competitive and efficient electric systems.

Enact electric utility restructuring legislation, develop advanced coall gas powerplants, improve existing nuclear powerplants

Objective 2. Significantly increase energy efficiency in the transportation, industrial, and buildings sectors by 2010.

Develop hore efficient transportation, industrial, and building technologies

Objective 3 . Increase the efficiency of Federal energy use. Adopt new/innovative energy-efiicient and renewable tecbnologies

Goal II. Ensure against energy disruptions - protecting our economy from external threat of internupted supplies or infrastructure failure.

Objective 1 . Reduce the vulnerability of the U.S. economy to disruptions in oil supply. Stabilize domestic production maintain readiness of Strategic Petroleum Reserve, diversify import sources, reduce consumption

Objective 2. Ensure energy system reliability, flexibility, and emergency response capability:

Ensure reliable electricity/gas supply, refining and emergency response

Goal II. Promote energy production and use in ways that respect health and environmental values - improving our health and local, regional, and global environmental quality:

Objective 1 . Increase domestic energy production in an environmentally responsible manner:

Increase domestic gas production, recover oil with less environmental impact, develop renewable technologies, maintain viable nuclear option

Objective 2 . Accelerate the development and market adoption of environmentally friendly technologies

Increase near-term deployment, expand voluntary efforts, design domestic greenbouse gas trading program, work with developing countries, design international trading/credit sysiem

Goal IV. Expand future energy choices - pursuing continued progress in science and technology to provide future generations with a robust portfolio of clean and reasonably priced energy sources.

Objective 1. Maintain a strong national knowledge base as the foundation for informed energy decisions, new energy systems, and enabling technologies of the future:

Pursule basic research, including research on carbon/climate; support energy science infrastructure

Objective 2 Develop technologies that expand long-term energy options

Develop long-term options, such as fusion, hydrogen-based systems, and methane bydrates, that can have major impacts

Goal V. Cooperate internationally on global issues - developing the means to address global economic, security, and environmental concerns.

Objective 1 Promote development of open, competitive international energy markets, and facilitate the adoption of clean, safe, and efficient energy systems. Encourcge adoption of favorable legal/policy framework in otber countries, promote clean efficient energy systems and science/ technology collaboration

Objective 2. Promote forefgn regional stability by reducing energy-related environmental risks in areas of U.S. security interest

Prioritize concerns and develop cost-effective solutions 


\section{Comprehensive National Energy Strategy}

\section{Energy - the Economy's Lifeblood}

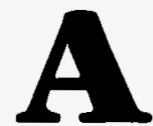

mericans share a desire for a high quality of life, characterized by good health, prosperity, security, and a clean environment. Government seeks to create conditions where these shared dreams have the greatest chance of being realized. Good energy policy can help us achieve each of these facets of the American dream.

Energy is the lifeblood of modern economies. It powers our factories, heats and cools our homes, and moves people and goods all with the flick of a switch or the turn of an ignition key. The lifestyle U.S. citizens enjoy, the envy of much of the world, was built in large measure on reliable, affordable energy supplies.

Energy is a global commodity. The price and availability of energy resources in one region can have global implications. Complacency about energy availability was shaken during the economic recessions that followed the two oil shocks experienced in the 1970s. The 1973 oil embargo and the 1978 Iranian Revolution showed how events thousands of miles away and largely outside U.S. control can disrupt our daily lives through impacts on energy markets and our national economy. In general, rising energy prices have tended to be associated with the onset of subpar economic performance [Fig. 1]. More recently, Operation Desert
Shield/Desert Storm in 1991 provided a vivid reminder that energy security cannot be taken for granted.

The 1970 s also witnessed broad recognition of the environmental consequences of energy use, such as urban smog and acid rain. New laws were enacted to counter the pollution from energy production and use. These were effective in lowering emissions and improving health, yielding substantial benefits that far exceed the incurred costs. This period also saw the dawning realization that greenhouse gas emissions from fossil fuel use could have global environmental implications.

During the late 1970s, it became apparent that the decades-old regulation of many energy prices was counterproductive and that the Nation should pursue marketoriented approaches to energy supply and use wherever possible. A consensus developed that competitive markets should be the cornerstone of a successful energy policy, but also that markets alone cannot be relied upon to achieve all of society's economic, environmental, and security goals because these societal benefits often are overlooked by the private sector.

The role of government in energy is now focused on the important tasks of improving the operation of competitive markets and addressing the market's inherent limits. This combined approach allows markets to be the key determinants of supply and demand, while government supplements market 
Figure 1

Relationship of world oil prices and U.S. gross domestic product (GDP), 1970-1996

International events outside our control bave caused sharp increases in energy prices, which in turn

bave been followed by slowdowns in the U.S. economy.

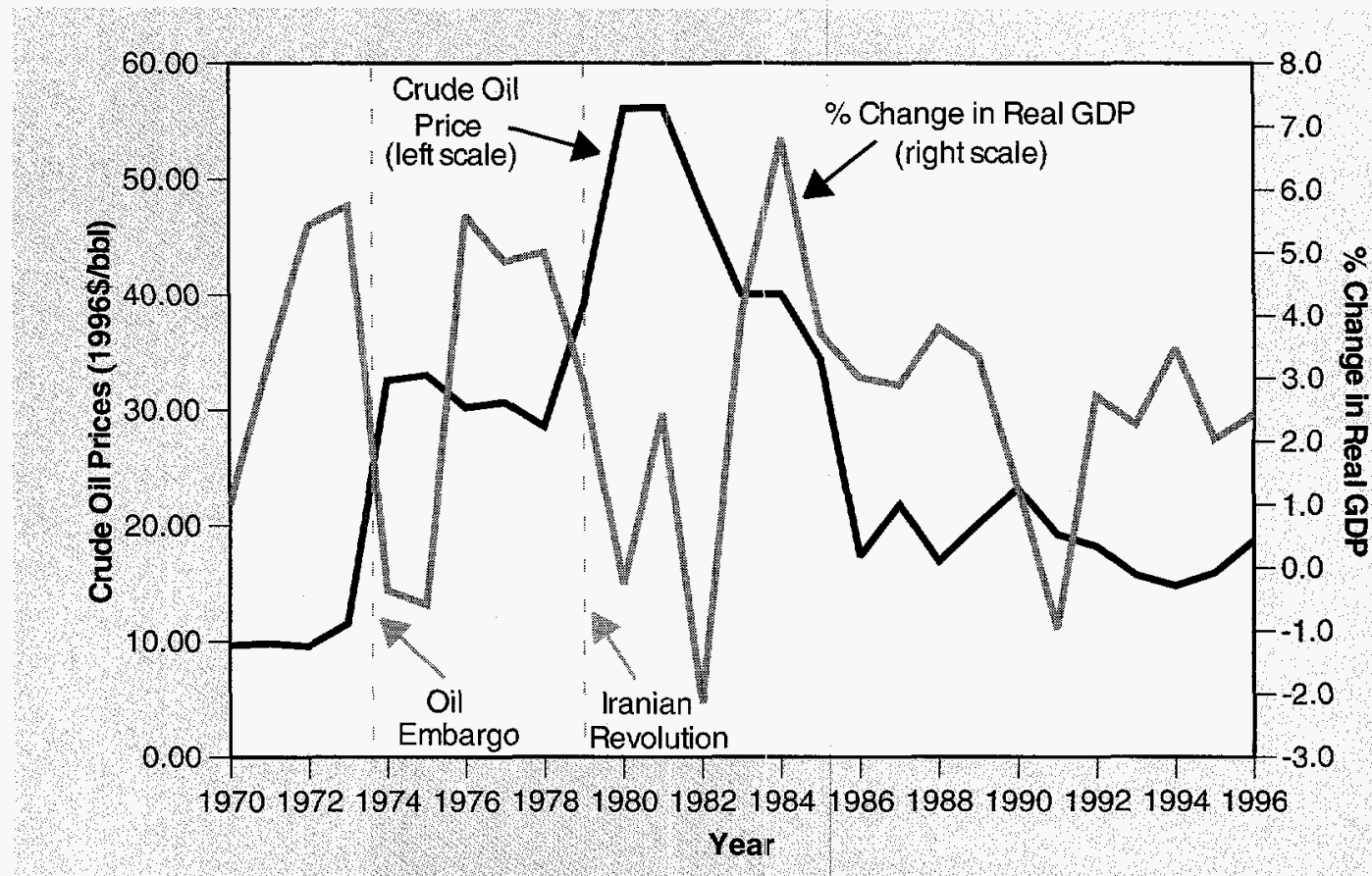

Source Energy Information Administration, Anmual Energy Review 1996, Table 1.6 (GDP values originally published by U.S. Department of Commerce)

forces through policies that bolster energy security and provide for a cleaner environment.

In this context, the Federal Government focuses on augmenting energy security by maintaining the Strategic Petroleum Reserve, coordinating emergency responses with our allies in the International Energy Agency, promoting increased domestic oil and gas production and use of alternative fuels, and maintaining military preparedness. The Federal Government also seeks to encourage favorable conditions in energy-producing regions of the world to facilitate access of all oil and gas resources to global energy markets. The Government reduces negative environmental effects by regulating pollution, limiting access to environmentally sensitive public lands and waters, and setting standards for energy use in consultation with the private sector. And the Government ensures the flow of new and cleaner energy technologies by funding energy research, development, and demonstration, often in concert with the private sector. Ultimate.y, the continued development of new technologies that provide diverse energy sources, improve the efficiency of end-use, and reduce the negative environmental effects of energy production and use is the key to maintaining our high quality of life.

Each day, most Americans depend on the benefits of energy, without always being aware of the role it plays in sustaining the quality of our lives. But this is not the case for many low-income households. While an average American family spends less than 5 percent of its income on household energy, poor families spend more, about 15 percent of income on home energy needs. This disparity is especially important during periods of energy price volatility. If cold weather and low heating fuel supplies cause heating fuel costs to spike, more affluent households can afford the increased cost. However, being cold is a possible, or even likely, outcome in lowincome households without government 
action. That is why the Federal Government provides funds to the States during such situations to help low-income families afford basic energy purchases and why it provides funds to weatherize homes to reduce the burden of high energy costs on low-income families.

The policy of establishing a relatively circumscribed role for the Federal Government has proven adaptable to changing economic, energy, and environmental circumstances. For example, by the late 1970s and early 1980s, succeeding Administrations allowed the price of oil products to rise as world oil prices increased. This policy encouraged consumers to reduce oil consumption and gave producers incentives to boost production, both here and around the world. From 1975 to 1985 , U.S. energy consumption relative to the level of economic activity decreased by about 25 percent; during 1985 alone, Americans saved more than $\$ 100$ billion (in 1996 dollars) in energy costs thanks to the technological improvements that occurred during this 10-year period. These market adjustments ultimately helped erode the Organization of Petroleum Exporting Countries' (OPEC) monopoly power in oil markets and paved the way for today's lower world oil prices.

\section{The U.S. Energy Landscape}

1 iven the central role of energy in our economy, it is no surprise that U.S. energy consumption has grown with gross domestic product (GDP). From 1970 to 1996, total U.S. primary energy consumption rose by almost 50 percent, from about 66.4 quadrillion Btu (quads) to about 94 quads. $^{1}$ In the same time period, GDP more than doubled [Fig. 2]. This energy and GDP relationship reflects improvements in the use of energy in this country as a result of technical progress and changes in the composition of the U.S. economy.
${ }^{1} \mathrm{~A}$ quad (which is short for 1 quadrillion British thermal units, or Btu) is a convenient, common unit for measuring large amounts of energy derived from different sources or used in different applications. A quad is approximately equal to the he:at content in 8 billion gallons of gasoline. The electricity component of end-use energy consumption is accounted for in terms of "primary" energy (the heat content of the fuel burned at the powerplant), not the electrical energy finally "delivered" to the customer.

\section{Figure 2}

Energy consumption and GDP, 1970-1996

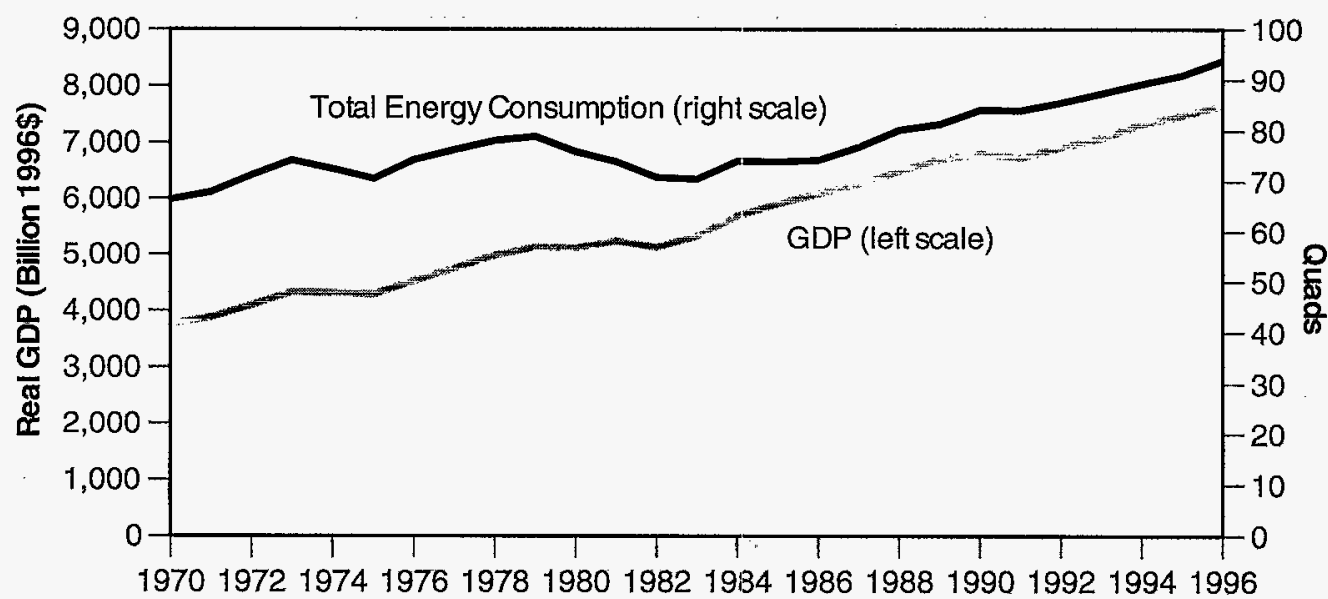

Source: Energy Information Administration, Annual Energy Review 1996, Table 1.6 (GDP values originally published by U.S. Department of Commerce).

\section{While U.S. energy consumption increased by almost 50 percent in the past 25 years, our gross domestic product more than doubled- a clear indication that we are using energy more efficiently.}




\section{Energy Consumption}

Energy is consumed in the four basic demand sectors of our economy: transportation, industry, residential, and commercial [Fig. 3]. In addition to energy used directly by these sectors, large amounts of energy are used to produce electricity.

Transportation accounts for about 26 percent of our Nation's energy use. ${ }^{2}$ The transportation sector accounts for about twothirds of all petroleum use in the United States.

Industry accounts for about 37 percent of U.S. energy consumption. Industry relies on a mix of fuels to produce a myriad of products and services. Petroleum and natural gas continue to be the major industrial fuels, together accounting for roughly 70 percent of direct consumption. Much of

${ }^{2}$ All statistics on current energy consumption and production are based on Energy Information Administration data for 1996.

\section{Figure 3}

Total U.S. energy consumption, by end-use sector, 1996 (total: 94 quads)

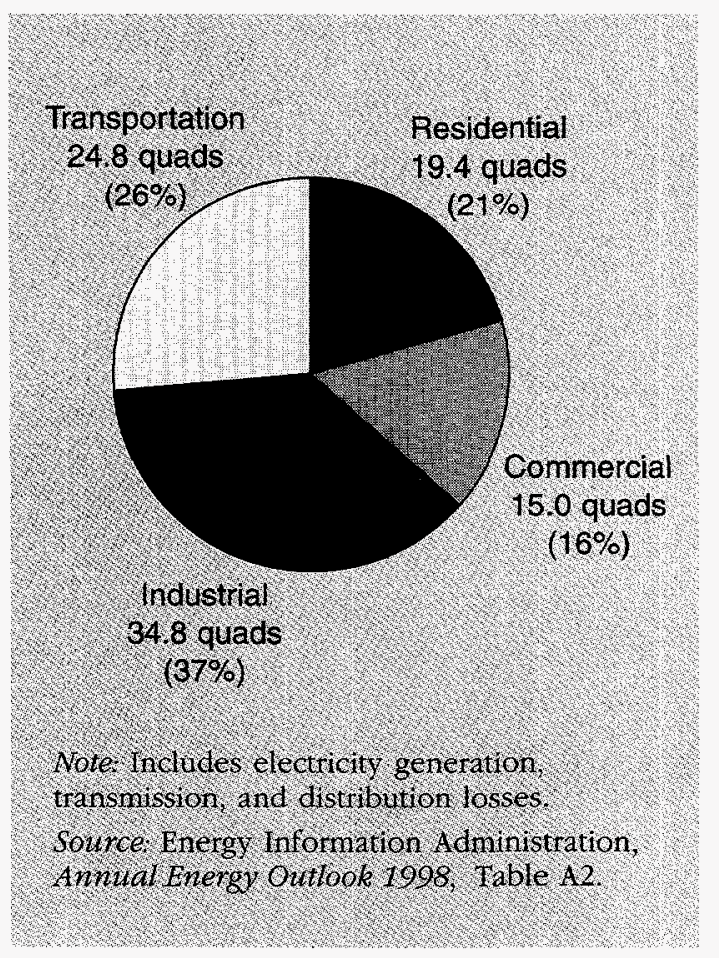

the petroleum consumption in the industrial sector is used as a raw material or feedstock.

The residential sector accounts for about 21 percent of total primary energy consumption. About 50 percent of all primary energy consumption in the residential sector is used for heating rooms and water; air-conditioning accounts for about 8 percent of consuraption; and major appliances (refrigerators, freezers, stovetops, ovens, washers, and cryers) are responsible for about 17 percent of residential consumption.

The commercial sector accounts for about 16 percent of total primary energy consumption. The diversity of building types found in the commercial sector and the variety of functions they perform create a broad range of energy needs.

\section{Energy Supply}

America's energy resources are extensive and diverse. Coal, oil, natural gas, and uranium are abundant, and a variety of renewable resources are available in large untapped quantities. The United States produces almost twice as much energy as any other nation, and nearly as much as Russia and China combined. Although our Nation uses most of this energy domestically, it exports considerable amounts of coal, refined petroleum products, and enriched uranium.

Domestic oil production accounts for about 22 percent of U.S. energy production, down from its share of 36 percent in the early 1970s [Fig. 4].

Natural gas accounts for about 27 percent of U.S. energy production. Although natural gas is produced in 33 States, Texas and its neighboring States, combined with the Federal offshore areas of the Gulf of Mexico, account for more than three-fourths of U.S. production.

Coal is the Nation's most abundant fossil fuel resource and accounts for about 31 percent of U.S. energy production. U.S. recoverable reserves of coal are greater than in any other nation, and more than twice those of China, the world's leading coal producer. Every year, the United States produces more than a billion tons of coal and exports roughly one-tenth of this production to a 
variety of markets. It uses almost 90 percent of the remainder to generate electricity.

Nuclear energy is the second largest source of U.S. electricity, after coal, producing more than 20 percent of our electricity.

Renewable energy includes hydropower, biomass (primarily wood and waste), geothermal, wind, and solar resources. These sources currently provide almost 10 percent of U.S. primary energy production. Although more than half of the U.S. renewable energy produced is used to generate electricity, it is also used for transportation fuels (such as ethanol), and for heating industrial processes (such as wood waste in the paper industry), buildings, and water. Renewable sources of electricity are dominated by conventional hydroelectric power, which provides 80 percent of all renewable electricity and 10 percent of total generation.

Electricity generation represents the conversion of energy from a primary source (fossil fuel, uranium, or renewable forms) into a clean, easily transported, and flexible secondary energy source with innumerable uses. U.S. electricity generation has grown almost every year during the past four decades. The United States is the world's largest producer of electricity, generating more than all of western Europe and Japan combined. More than half of all electricity is generated by burning coal; about one-fifth is derived from nuclear powerplants; renewable resources - primarily hydropower provide about one-eighth; and the remainder is fueled by natural gas (about 9 percent) and oil (about 2 to 3 percent).

\section{A Changing Energy World}

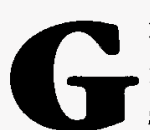
rowing populations and rising living standards, economies in transition to market-based systems, and increasing globalization of energy markets demand greater flexibility and creativity in government economic, environmental, foreign, and national security policies. Energy policies, too, must be reevaluated in the wake of the experiences of the 1990s. Three preeminent challenges emerge: how to main-

\section{Figure 4}

U.S. energy production, by fuel, 1996

(total: 72.6 quads)

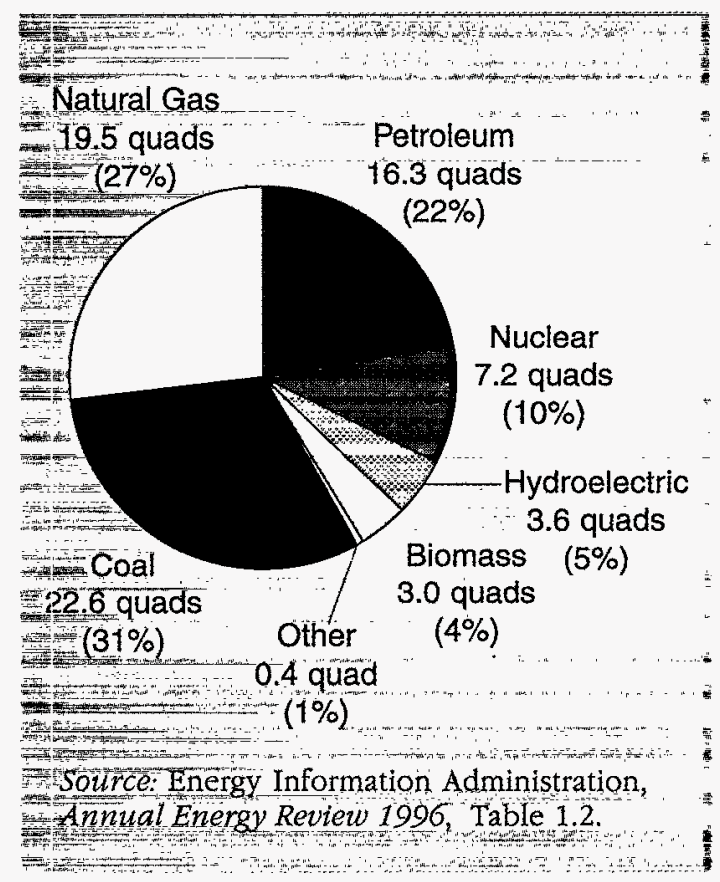

tain energy security in global energy markets; how to successfully harness competition in electricity markets; and how to respond to the threat of climate change.

\section{Global Economic Transformation and Energy Security}

The end of the Cold War unleashed market forces in one country after another, and many countries are in the process of transforming cumbersome, government-run energy sectors into private enterprise. Indeed, most of the global energy economy is now directed by market forces, as opposed to government fiat. At the same time, economic policies in the developing world have led to doubledigit growth rates, significant increases in energy demand, and substantial inflows of private capital to finance expanding energy sectors. As a result, world energy use has grown and its composition has shifted [Fig. 5].

Projections of brisk growth in world oil demand substantially change the energy security outlook. In oil production, geology
Fossil fuels account for 80 percent of the energy produced in the United States (and 85 percent of the energy we consume). 


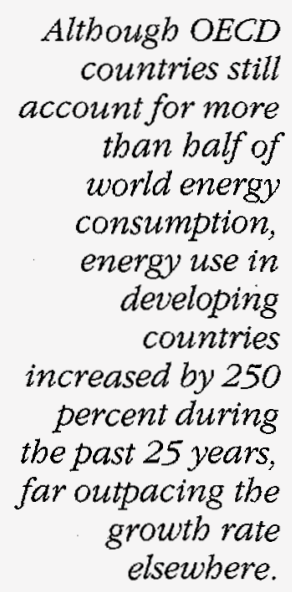

Altbough OECD

than half of

world energy

consumption,

nergy use in

eveloping

coun 250

percent during

the past 25 years, growth rate elsewbere.

\section{Figure 5}

World primary energy use, 1970-1995

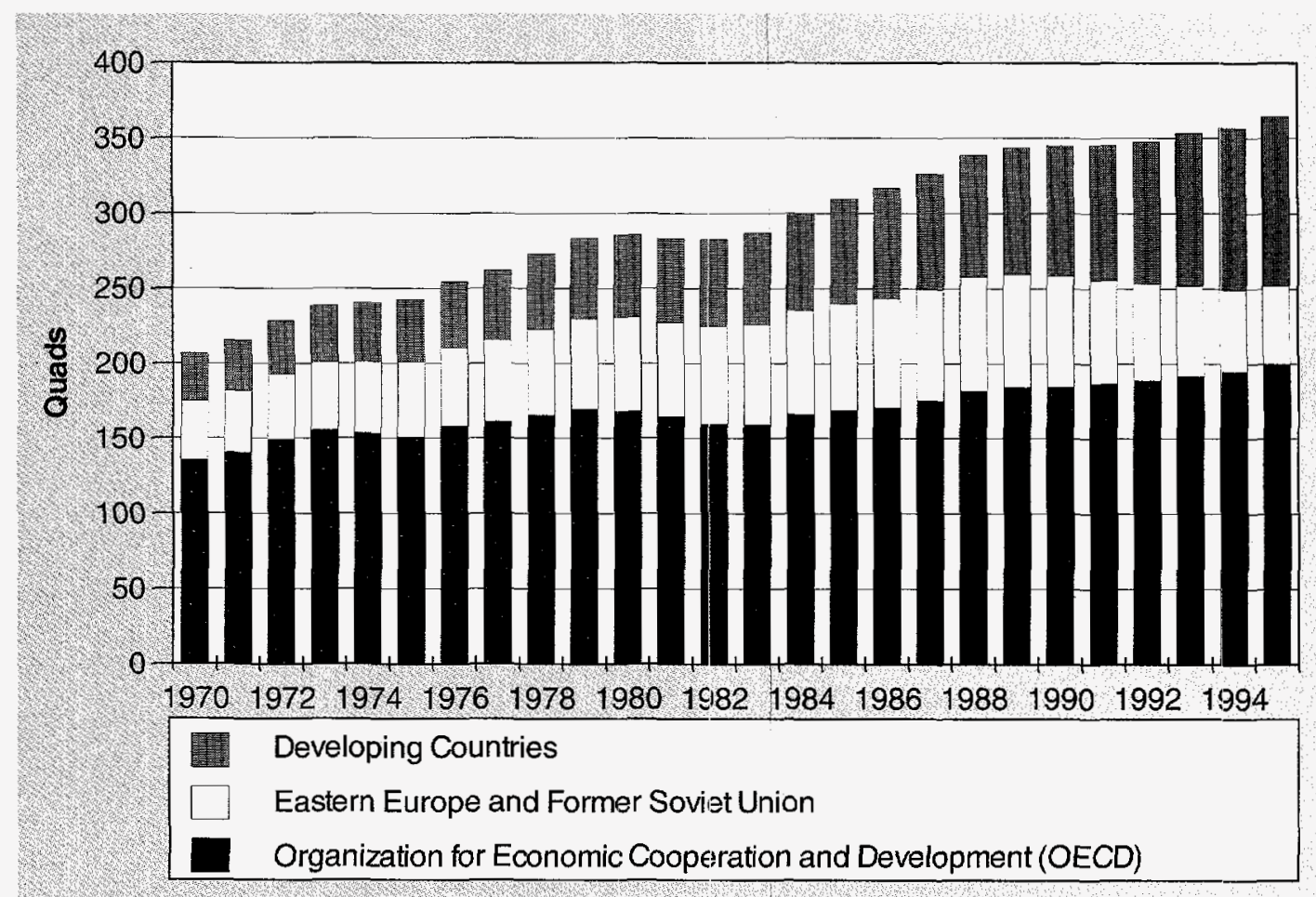

Solirce: Energy Information Administration, International Energy Annual 1996, Table E1, and unpublished data. is destiny. Roughly two-thirds of the world's proved oil reserves lie in the Persian Gulf region. Even with development of the resources in the Caspian region, rapid growth in world oil demand will likely be met primarily through growth in Persian Gulf oil exports [Fig. 6]. Excessive reliance on a single geographic area to satisfy increased world demand for oil creates the potential for oilimporting nations to be vulnerable to supply distuptions and price volatility. This risk can be minimized by coordinating policies with our allies in the International Energy Agency and by maintaining or enhancing our Strategic Petroleum Reserve.

\section{Competition in the U.S. Electricity Market}

Closer to home, the success of deregulation in the oil and natural gas industries, along with the consumer benefits flowing from de- regulation in other sectors once dominated by regulated monopolies, has prompted consideration of deregulating major portions of the Nation's electric power industry. Federal legislation enacted in the late 1970 s and early 1990 s has opened the wholesale power-generation sector of this industry to competition, and several States are in the process of implementing competition in retail markets. While a few States with relatively high electricity rates have led the way in aggressively pursuing competition, most States have just begun to examine prospects for competition to lower prices [Fig. 7].

\section{International Response to Climate Cbange}

The 1990s have seen the global climate change debate evolve from an issue discussed largely among scientists to one that engages the collective attention of governments around the world. In December 1997, 
Figure 6

Persian Gulf share of world's oil exports, 1970-2020

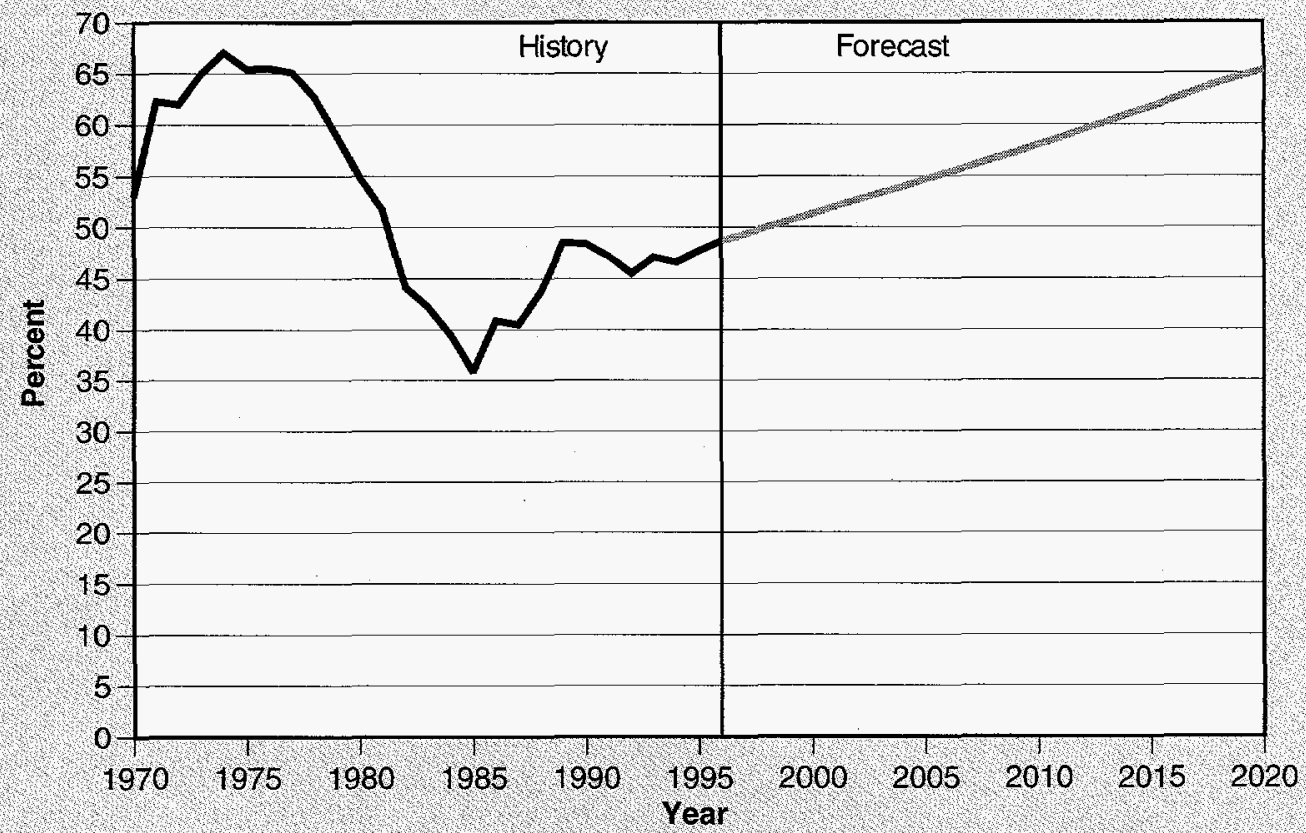

Source Energy Information Administration, 4 mnwal Energy Oullook 1998, Figure 28.

\section{Figure 7}

Electric power industry restructuring activities, showing current State average electricity rates (cents per kilowatthour)

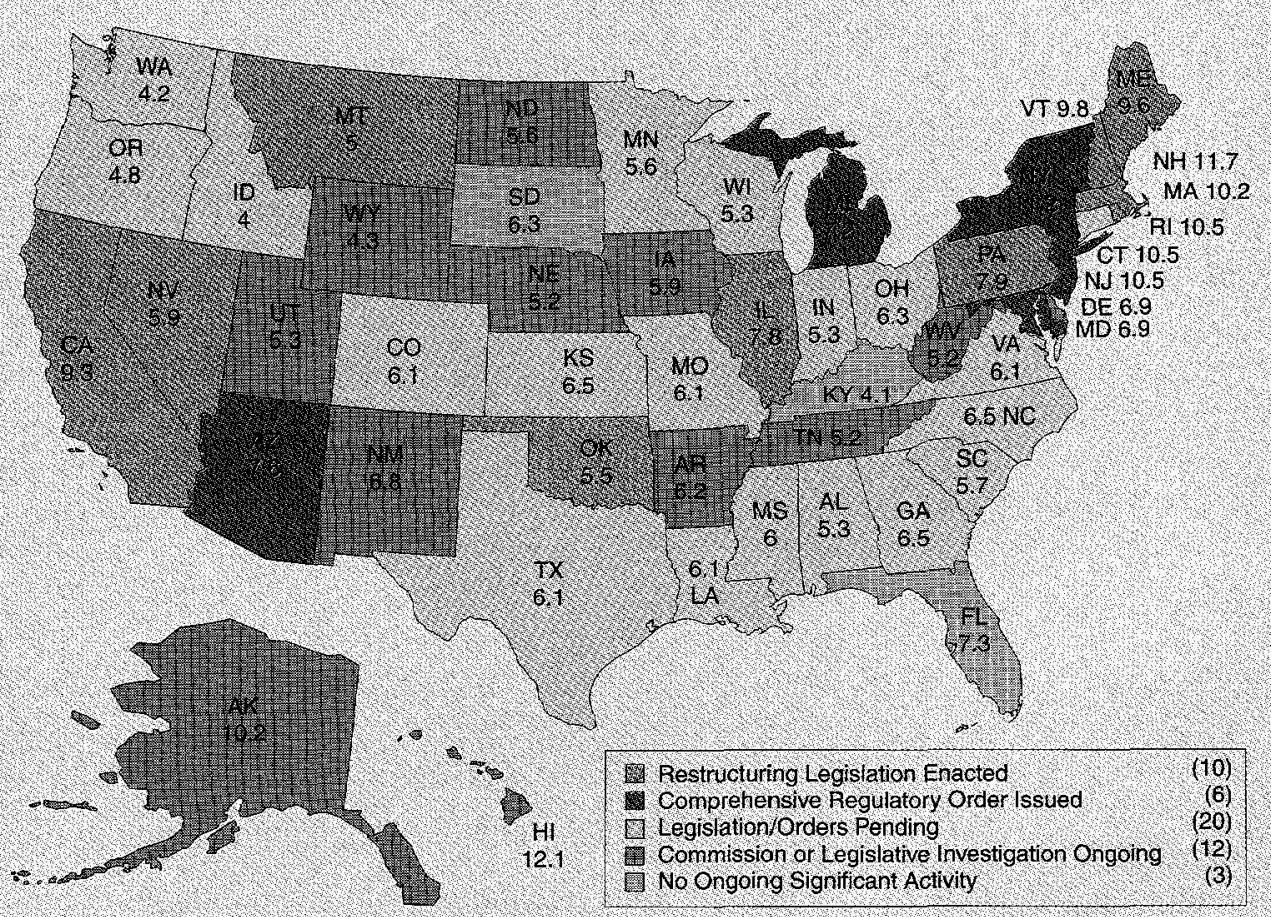

Note: Information current as of April 1998.

Source: Energy Information Administration and Energetics, Inc
According to

Energy

Information

Administration

projections, oil exporters in the Persian Gulf are on a path to recapturing their bistorically bigh share of the world oil market.

Most States are actively pursuing changes that will bring greater competition to the electric power industry - and lower electricity prices to consumers. 


\section{Figure 8}

U.S. energy-related carbon emissions, 1980-2020

Witbout serious efforts to change our patterns of energy production and use,

U.S. emissions of green bouse gases will continue on a steady upward climb.

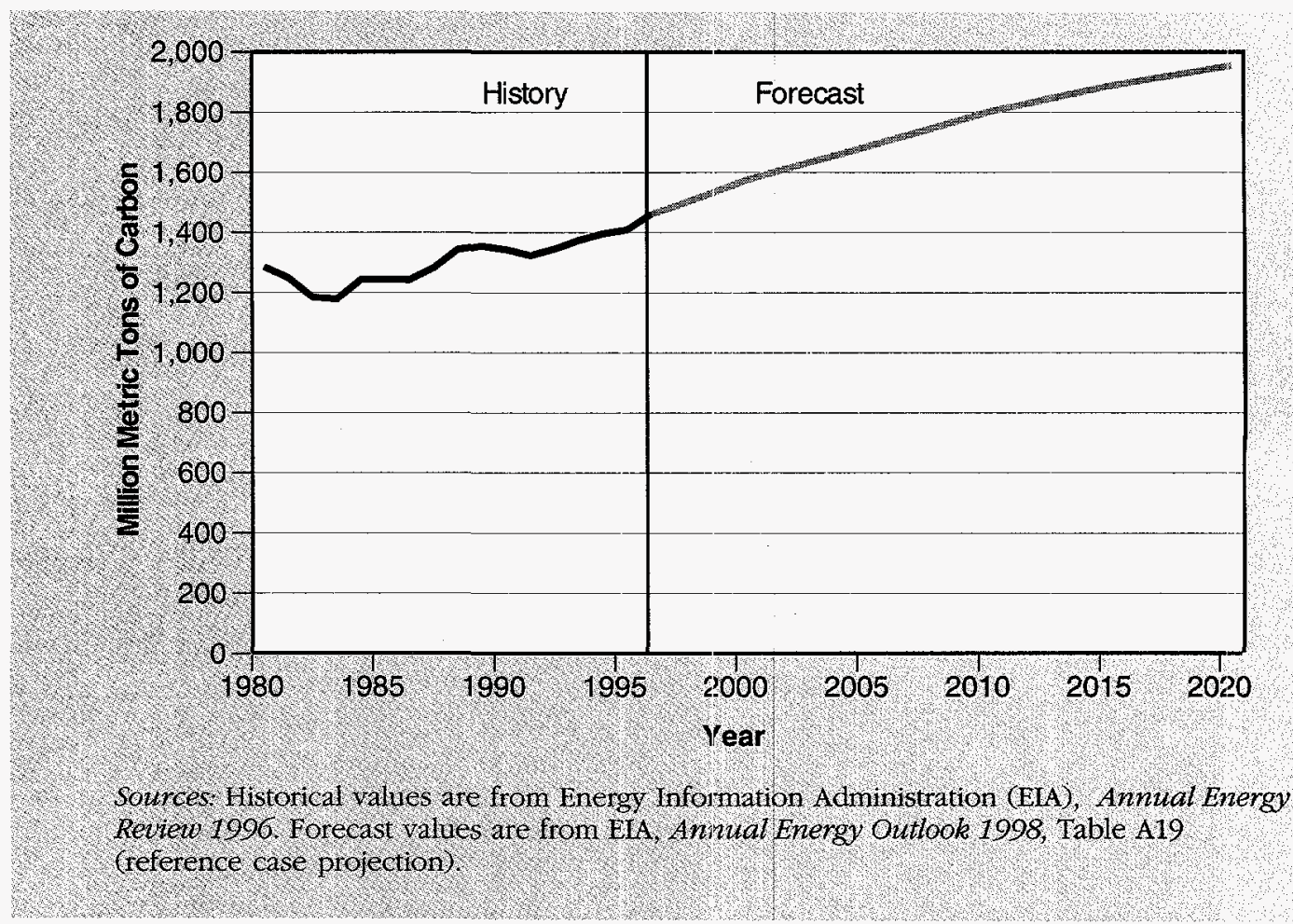

the international community negotiated the Kyoto Protocol to the United Nations Framework Convention on Climate Change, which includes targets for developed countries for reducing greenhouse gas emissions. Given that more than 80 percent of human-made greenhouse gas emissions are energy related, and that energy consumption continues to increase, energy policy has a new and demanding role [Fig. 8].

The Kyoto Protocol calls for the United States to reduce its average annual emissions to 7 percent below 1990 levels over the period 2008-2012 (measured net of baseline adjustments for hydrofluorocarbons, perfluorocarbons, sulfur hexafluoride, and carbon sequestration). This target entails significant emissions reductions when compared with recent projections, though not all of the reductions will come from energy sectors. Thus, the Kyoto Protocol, if the United States Senate gives its advice and consent to ratification, may set our Nation on a very different course toward an important and challenging goal. Attaining this tar- get while preserving U.S. industrial competitiveness will require a blend of market-oriented policies with structured government involvement. However, the United States will not ratify the Kyoto Protocol without meaningful participation by key developing countries in the global response to the threat of climate change. [See Appendix A for further details on the Kyoto Protocol.]

\section{Energy Technology: The Essential Basis for Progress}

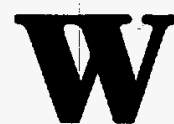

ithout energy technologies, a ton of coal, a barrel of oil, a cubic foot of natural gas, a ton of uranium ore, a stiff breeze, or the Sun's warrnth cannot directly contribute to the prosperity of modern society. With the very best technologies, however, society can use energy resources efficiently and responsibly and with great economic and environmental gain.

While economic and security challenges continue to demand investment in a robust 
energy research and development (R\&D) program, environmental challenges provide special impetus for increased focus on energy-related science and technology during the coming years. Energy use is the principal cause of local and regional air-quality problems, such as the emission of fine particulates and the creation of smog and acid precipitation from nitrogen and sulfur oxides. On a global scale, there is little doubt that human activities associated with energy production and use have, over the last few decades, significantly altered the composition of atmospheric gases. In particular, the concentration of carbon dioxide, a greenhouse gas, has increased by a third over preindustrial levels. Once released, carbon dioxide remains in the Earth's atmosphere for a century or more. The great majority of involved scientists agree that "business as usual" greenhouse gas emissions will lead to significant increases in average global temperature and associated climate changes, although the magnitude and distribution of the ecological and human consequences remain the subject of research and debate. Prudence clearly dictates that new technologies be developed to provide additional options to meet evolving environmental, economic, and security needs.

The imperative for embarking on a strong technology program now is reinforced by recognition of the long periods of time associated with significant change in our energy infrastructure. Research and development itself often takes one or two decades to yield technological breakthroughs. The life expectancy for major energy supply and end-use technologies also extends to many decades. Decisions made every day about energy production and use commit the $\mathrm{Na}-$ tion to a certain energy path for what can be a considerable period of time. To the extent that economically attractive, clean, and efficient technologies are chosen, both the economy and the environment benefit. Thus, a robust energy $R \& D$ program is needed to enable us to achieve a healthy and prosperous future.

Over the next 10 to 15 years, advances in energy efficiency offer the greatest op- portunity for serving environmental, economic, and national security goals. The scale of potential gains is established by the magnitude of our Nation's total energy expenditures (about $\$ 500$ billion per year) or of total manufacturing expenditures on energy (about $\$ 100$ billion per year).

Renewable energy technologies, those that harness the enormous energy available in natural systems, can be expected to make major contributions to our Nation's energy portfolio in coming decades. They will help meet energy needs in transportation, commercial and residential buildings, and industry with limited environmental impact. The scale and timing of market penetration will depend on further technological progress and the evolving regulatory framework. In addition, the continued operation and optimization of existing nuclear powerplants through advanced technologies may be an important contributor to meeting greenhouse gas emission-reduction goals if issues such as nuclear waste disposal and nonproliferation are resolved satisfactorily. In the longer term, fusion energy could also contribute to stabilizing and reducing the atmospheric concentration of greenhouse gases.

Advances spawned through American innovation will range from improvements seen directly in our everyday lives - much more efficient light bulbs, cars, appliances - to new approaches for large baseload energy sources. The Nation must engage the talent in our universities and national laboratories to advance basic science and engineering research and to partner with the private sector to develop and deploy new technologies. This is a central component of a modern, forward-looking energy strategy.

\section{Proposed National Energy Goals}

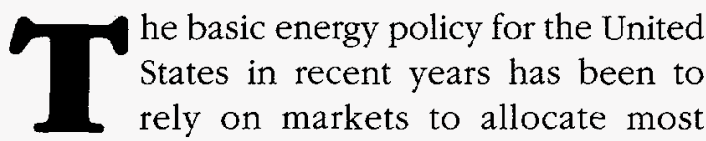
resources with selective government intervention to ensure that certain highly valued societal needs - including the need for energy security, environmental quality, and en- 
ergy research - are met. While this general market-based approach to meeting energy challenges has endured, the precise blend of market reliance and government action is subject to substantial debate. The debate stems from different perceptions of market shortcomings and risks, varying degrees of emphasis on specific policy goals, as well as disagreement over the best strategies to be used.

In the past 5 years, the Administration has pursued an energy policy that has provided substantial economic, environmental, and national security benefits for the American public. This policy, however, has been based on a legislative and regulatory framework last revised in the early 1990s. It is now time to take stock of our Nation's energy progress, identify the most substantial challenges that remain, calibrate energy policy goals to the new century, and propose long-term solutions.

In the context of pursuing a marketbased energy policy, this Comprehensive National Energy Strategy proposes five specific goals for the Nation. These goals arise out of the shared desires of all Americans to improve the quality of life through higher living standards, economic security, and a clean environment. A common thread running through our national response to these goals is development and deployment of new technology, achieved through basic scientific and engineering advances. While these goals are not new to this Administration, they are linked with specific proposed strategies that reflect the evolving energy environment. The proposed goals are:

- Improve the efficiency of the energy system - making more productive use of energy resources in order to enhance overall economic performance while protecting the environment and advancing national security.

- Ensure against energy disruptions protecting our economy from external threat of interrupted supplies or infrastructure failure.

- Promote energy production and use in ways that respect health and environmental values - improving our health and local, regional, and global environmental quality.

- Expand future energy choices - pursuing continued progress in science and technology to provide future generations with a robust portfolio of clean and reasonably priced energy sources.

- Cooperate internationally on energy issues - developing the means to identify, manage, and resolve global economic, security, and environmental concerns.

These goals are interrelated, with tension among some and opportunities for synergy among others. Nevertheless, pursued simultaneously through a comprehensive market-based energy strategy, the attainment of these goals will produce payoffs greater than the sum of their individual components. These goals form a durable framework against which future energy initiatives should be judged to see if they are consistent with the national interest.

The term "comprehensive" in Comprehensive National Energy Strategy does not mean that every program, initiative, and technology that can help meet our national energy goals is included within these pages. Rather, this document is intended to be a blueprint. The Strategy will be used to coordinate energy-related programs, throughout the Administration, that implement the overall energy strategy reflected in these pages. It will specifically be used in developing future budgets, evaluating future legislative initiatives, and managing the Administration's energy-related programs.

\section{Goal I}

Improve the efficiency of the energy system-making more productive use of energy resources to enhance overall economic performance while protecting the environment and advancing national security.

To compete successfully in world markets and to improve living standards, the United States must achieve more productive 
and efficient use of its energy resources, including its electricity infrastructure, its fossil fuel reserves, and its productive capacity for clean, alternative fuels. In addition, the Federal Government must find new ways to buy and use energy. Among other things, these actions also will help reduce reliance on imported oil from unstable regions of the world.

\section{Objective 1. Support competitive and efficient electric systems.}

Strategy 1. Enact legislation to promote the establishment of a competitive electric system with improved environmental performance. The Administration supports comprehensive legislation that will promote efficiency, increase use of renewable resources, reduce emissions, lower costs for consumers, and allow electricity suppliers to provide value-added services. The existing Federal regulatory framework impedes the evolution of the electric marketplace. It prohibits some desirable actions by regulators and corporate decisionmakers; it requires companies to take some actions that are uneconomic; and it fails to give clear, unambiguous guidance to Federal and State regulators concerning who has authority to do what in an industry that is undergoing significant change. The Administration's Comprehensive Electricity Competition Plan would correct these problems. This plan is summarized in the box on this page.

Strategy 2. By 2010, demonstrate costeffective power systems that acbieve electrical generating efficiencies greater than 60 percent using coal (compared with an average of 35 percent today) and 70 percent using natural gas (compared with about 50 percent today). Total fuel efficiency will reach 85 percent in combined beat and power applications. Expanded R\&D can accelerate the availability of advanced turbine and fuel cell technologies, which can be combined to raise the efficiency of new gas-fueled powerplants to 70 percent. These technologies can also be combined with advanced coal technology, such as integrated

\section{The Administration's Comprebensive Electricity Competition Plan}

The Administration believes that Federal legislation is needed to accelerate and guide the transition of the U.S electric industry towards greater rellance on competilive narket forces, It has issued a Comprehensive Electricity Competition Plan that outlines detalled specifications for provisions that Congress should enact in a single, comprehensive elec tric bil. The Administration ex pects that its plan wil result in substantial benefits for both the economy and the environment. These benefits include:

- Reduction in the Nations s elec tric bill by at least 10 percent (or $\$ 20$ billion per year $1 \mathrm{~h}$ current dollars).

- A significant down paynent toward reduction of greenhouse gas emissions, with a 25-11illion to 40 million net ric ton reduction in carbon emissions projected in 2010 .

- A substantial increase in the use of nonhydro renewable energy sources by 2010 , nore than doubling the level of use projected without the plan.

The plan would a chieve these benefits by:

- Establishing clear Federal policy support for wholesale and retail competition in the industry.

- Maintaining flexibility for State and local governments to develop approaches to retail competition that reflect unique local conditions.

- Maximizing consumer benefits by providing mechanisms and authorities to ensure that real competition occurs, and by requiring uniform easy-tounderstand labeling that will empower consumers to make informed choices.

- Supporting low-income assistance, energy efficiency, renewable energy, and other public benefits through a Public Benefits Fund (PBF) and a Renewable Portfolio Standard (RPS)

- Reducing emissions through competition, which encour ages efficiency, green power. and innovative services, and through the PBF and RPS proposals.

- Strengthening electric system reliablity while bullding on the industry's tradition of self-regulation by requiring key market participants (in chiding Federal power sys tems) to join an organization that would establish and enforce rellability standards subject to the oversight of the Federal Energy Regulatory Commission

- Clarfying key authorities for Federal and State agencies with respect 10 governance of the new electricity industry

- Allowing existing public power faclities used in competitive electricity markets to retain tax-exempt financing.

- Providing rading authority for nitrogen oxide emissions to facllinte cost-effective, markel-driven reductions of nitrogen oxides.

The plan removes barriers in existing federal law that are impeding the transition to competition already under way. The major provisions of law were crafted in 1935, when competition was not contemplated Existing laws block economically desirable actions, fail to give adequate guidance to Federal and State regulatory authorities regarding their respective purisdiction under competition, and fall to give clear policy guidance on many inportant new questions related to competitive electricity markets. 


\section{Cars of the Future}

By 2010 , you may be driving a car that gets $80 \mathrm{mpg}$, emits vir tually no pollution, has the ac celeration, driving range, safety, and other petformance charac teristics to equal the best of today's cars - and is still afford. able.

Such dramatic progress will come from totally reinventing how vehicles are powered, and from the use of advaneed IIght weight materials and aerody namic designs in the body and chassis. While the exact layoul needs further research, the cars of the 21st century will likely have an electric motor to drive the wheels, with the electric power coming from new powerplants - two promising technologies are an advanced compression-ignition engine combined with batteries, and a space-rge device known as a fuel cell.

The design that features an engine and batteries is furthest along. Such vehicles with dual power sources are called hybrid vehicles, the primary power comes from the engine, but the batteries provide extra power acceleration and store any extra electricity generated by the engine. These hybrids will get at least twice the fuel econony of today s cars and have the potential to produce lower emissions Even higher efficiencles nay come from making these hybrid vehicles of new materials, such as carbon fiber composites, that are Iighter but stronger than those used today.

Fuel cells require nore de. velopment but offer additional advantages. Technically, fuel cells are not really engines. since they convent a fuet such as hydrogen directly into electricity without burning it, and the electricity is used by electric motors to power the vehicle. Fuel cells are nilch more efficient than any engine. They can also use fivels other than hydrogen, converting them into hydrogen while giving off only snall amounts of pollutants, with no noving parts, fuel cells are silent and potentially almost main. tenunce free.

Both new approaches could be used for a wide range of vehicles - from trucks, buses, and commercial vehicles to passen. ger sedans and sport utilty vehicles. And while lower fuel costs wil benefit the owners, the broader national benefits could be even more important. With widespread use, both hybrids and fiel-cell vehicles would redice urban air pollution and cut dependence on imported oll fuel. cell vehicles, for example, are expected to be 70 to 90 percent cleaner than todays cars. When they comprise just 10 percent of the U.S vehicle fleet, hey would reduce oil imports by $130 \mathrm{mi}$ lion bartels per year. 1igher ef ficiencies also transhate into lower enissions of carbon dioxide, reducing pressures on the global dimate Moreover, leadership in producing such vehides, which are expected to be popular around the world could prove a conpetitive advantage

Although several auto compa. nies in the United States and elsewhere have bull protolypes of these new vehicles, hey are not yet ready for conmerial prodic. tion and need further work. Fuel cells, in particular, must be made smaller, lighter, and less costly. But the pace of development is accelerating. Early in the $21 \mathrm{st}$ century, these new vehicles are likely to begin rolling off assernbly lines and onto the highway. combined cycle, to achieve efficiencies of more than 60 percent. Even higher thermal efficiencies - over 85 percent - are possible for manufacturing applications that require both process heat and electricity.

In the nearer future, to meet new a.irquality standards for microscopic particulates (PM2.5), enhanced R\&D will seek ways to reduce both primary particulate emissions and emissions of sulfur and nitrogen oxicles that are precursors to secondary particulate formation in the air. Also included in this effort is development of technologies to meet new standards for ozone and pending standards for visibility and air toxics.

\section{Strategy 3. Improve the reliability and per- formance of the operating nuclear plants, which number more than 100, to belp meet the Nation's future electrical power nee'ds more efficiently. U.S. nuclear powerplants should see improvements in operating ca- pacity - as much as 10 percentage points in the next several years (from 76 percent to 86 percent) - with further technological de- velopments. A performance improvement of this amount in the operating plants would offset as much as 10,000 megawatts of ne:w electrical output capacity.}

\section{Objective 2. Significantly increase energy efficiency in the transportation, industrial, and buildings sectors by 2010.}

Strategy 1. Develop more efficient technologies for the transportation sector. The U.S. transportation sector accounts for two-thirds of the Nation's annual oil consumption and depends on oil for 97 percent of its fuel. Current trends in energy demand, particularly for oil, can be significantly altered by developing enabling technology to support commercialization of a personal vehicle capable of three times the fuel efficiency of conventional vehicles by 2010 ; lighter, cleaner heavy-duty vehicle engines; advanced aircraft engines and airframes; and fuel cells for transportation use by 2005 . To ensure that more fuel-efficient vehicles enter the marketplace, the President has pro- 
posed tax credits of $\$ 3,000$ to $\$ 4,000$ for consumers who purchase advancedtechnology, highly fuel-efficient vehicles [see Appendix B]. Research to improve the energy efficiency of other modes of travel is also under way; for example, the Department of Transportation is developing fuel cells for use in marine powerplants. Ways to improve the operation of our transportation system are being developed to reduce traffic congestion on highways and at airports.

Lastly, demand for transportation energy can be fundamentally altered by developing communities that are less dependent on automobiles. Sustainable community development can offer residents a mix of transportation services that make walking, biking, and public transit viable alternatives to drive-alone travel. The Department of Transportation will work with local and State decisionmakers to develop the tools and resources required to encourage pedestrianand transit-oriented development and the integration of a full range of transportation alternatives.

\section{Strategy 2. Develop more efficient technolo-} gies for the industrial sector. Industry consumes more than one-third of the energy delivered in the United States. Developing and implementing technology roadmaps (detailed plans for research, development, and deployment of industrial technology) leading to a 25-percent reduction in expected energy consumption of the six most energyintensive industries in the United States by 2010 is a key element for meeting this objective. These six industries are the forest and paper products, steel, aluminum, metal casting, glass, and chemicals industries, which account for more than half of all manufacturing energy use. Crosscutting technologies such as advanced turbine systems, combined heat and power systems, advanced materials, and sensors and controls will be part of this R\&D effort to increase energy savings and industrial productivity. To accelerate their entry into the marketplace, the President has proposed a 10-percent investment tax credit for the pur-

\section{A Tale of Two Houses}

lmagine two conventional frame houses, both buil onsite Imagine they look the sane and cost the same, One house, however, uses 50 percent less energy and is more comfortable to lve in than the other, with no drafts or cold walls yet with betrer vent lation. The difference is better design, more nsulation better windows, and smaller but more effictent furnaces and ar condi. tioning equipment what is known in the industry as best practices? The more energy efficient house is clearly a bet ter deal for the home buyer, if requiring a more houghiful effort on the part of the buildet. Nationally, the payoff is even greater reduced energy needs, less pollution, less waste of materials. Nearly 20 percent of U.S. energy consumption, af ter all, occurs in the home. In der a loint government-industry program, some 10,000 bestpractice homes are to be built in the next few years.

But could houses becone even more energy efficient, even more confortable and convenient to live in? Might the house of the future cut energy use even further, to 25 percent of present levels or less? Bullding scientists and engineers think it's possible.

To stant with, the house of the future is likely 10 be designed and oriented on the lot to take full advantage of he sun- for natural Iight, for heating, even for generating its own electricity with photovoltaic loof panels Equally important, the house is likely to beneft from mass custunization t based on com puter-aided design toris, so that it meets the needs and tastes of different buyers who can even "walk hrough" the house on a computer screen of a wir tual reality display before the design is final. yet is optinised as a complete system to make sure components work together and to save costs, energy, and materials.

The house of the future is also 1Kely to be built at least partly in a factory, for letter quality control and lower costs, and shipped as modules or large components to the site for quick assembly. Bulling materials are lighter. stronger, and more environmen. tally friendly Paints, wall fabrics. and carpeting do not enit organic compolinds.

Advanced high efficiency lighting is integrated with naturallight and appliances vith heat ing and cooling systems. The house night not only generate nuch of its own electricity - elther from photovoltale roof pan. els of from fuel cells - but might also sell excess power to the elec. tricity company. The warmth from waste hot water and from stale air flushed by the ventilation system is recaptured, and waste water itself from sinks and showers used for flushing tollets or irrigating the garden.

Sensors throughout the house monitor temperature, humidity light and perhaps the presence of people. Smant appliances and house control systems adjust to mateh the weather occupancy palterns, or the instructions of their owners, turning on lights when people enter a roon or preheatitg the oven or the racuzzi in response to a telephore or e man signal.

Naking all Wese aspects of the house of the fulure come 10 . gether reguries more research to reduce costs and efforts to link together the whole chain of sup pliers and builders involved in the housing Industry. But the technologies already exist, at least in preliminary form. In per. haps a decade of two, look for some radieal improvements in whats offered in new housing developments. 


\section{Self-Powered Buildings}

Two decades from now, chances are that many office bulldings. hospitals, shopping nalls, and other commercial bulldings will be self-powered, generating most of their own electricin and even selling excess power to the electric company. The technological revolution at the root of this transformation is the fuel rell.

These devices, first used in the space program, are now coming down to earth, with anits of the size to power a conmercial building already avallable. Because fuel cells generate electricity by converting natural gas or a similar fuel electrochemcally, like a battery, they have no moving parts and ate silent. In addition to electricity, they produce heat and hot water and thus could replace furnaces and water-heating equipment. And because they operate onsite. there are no high-vollage transmission losses. Consequently. fuel cells offer significant gains in energy efficiency and major reductions in pollution.

Fuel cells lend themselves to a vision of a distributed power generation system for the United States, one that could signifi cantly reduce the need for new centralized power stations and long transmission lines. With fuel cells installed in of near corl mercial buildings and as neighborhood powerplants in residential areas, the electrical grid would serve mostly to help redistribute excess power to ar eas where it is needed.

Based on its experience with fuel cells, Southern California Gas Company says that these devices are especially useful in facilities like hotels and hospl- tals that require power and hot watet at all hours of the day. The water discharged from fuel cells is extremely clean and needs no treatment before use. In one Hyatt facilly, a fuel cell provided 20 percent of the hotel's peak electricty needs. 90 percent of its space heating, and some of its hot water.

Fuel cells are still relatively expensive. Improved designs and more auromated production techniques will be needed to bring costs down by at least a factor of two before widespread use in buildings is likely That may happen as soon as the middle of the next decade, technical experts say. Improvements are planned both in the reformer. which converts natural gas to hydrogen, and in the fuel cell itself, which combines hydrogen with oxygen from the air 10 gen erate power.

A crucial part of a fuel cell is the electrically conductive naterial, or electrolyle, in which the chemical process takes place. One current design uses a phosphoric actd electrolyte and achieves efficiencies of about 36 percent, but cells based on several other materials are under development and may acheve efficiencles as 1 igh as 50 percent. Overall efficiencies can reach 85 percent when the cells heat output is also used

With this porential for effi crent, clean, distributed power generation. it is no wonder that fuel cells seem likely to transform the way buildings get their power in lie 21st century some com panies are already talking about units small enough to power in dividual houses or even cars (see Cars of the futwre on page 12 ) chase of combined heat and power systems [see Appendix B]. In addition, governmentindustry cooperation helps to save energy with the Motor Challenge program, Climate Wise program, and others. These efforts help ensure the use of best-practice technologies and provide a more receptive market for advanced energy-efficiency technologies.

Strategy 3. Develop more efficient technoiogies in the buildings sector. America's buildings, including heating and cooling equipment, lighting, and appliances, consume 37 quads of energy each year, accounting for 39 percent of the Nation's energy bill. By 2010 , research, regulation, and technology transfer - in partnership with indu.stry, the research community and State and local entities - can save 2 quads annually, partly through avoiding the need for $150 \mathrm{bil}-$ lion kilowathours of electricity and partly through savings in natural gas. These paitrerships can encourage innovation in building design and energy technologies and deployment of efficient technologies, with an emphasis on effectively integrating all $e-1-$ ements of building energy use. In addition, building-sector partnerships can contribute to the development of more cost-effective national standards and improved test procedures for energy-consuming appliances and equipment. To spur the use of more energy-efficient technologies in the buildings sector, the President's proposed tax program includes a 20-percent credit (subject to a cap) for purchasing energy-efficient building equipment and a $\$ 2,000$ credit for purchasing energy-efficient new homes [see Appendix B]. Also, government-industry cooperation helps consumers purchase energyefficient appliances and equipment throug; h labeling and the Energy Star program.

\section{Objective 3. Increase the efficiency of Federal energy use.}

Strategy 1. Improve the efficiency of energy use in Federal buildings. Executive Order 12902 calls for reducing energy use in Federal buildings by 30 percent by 2005 , compared to 1985 levels. Since 1985, Federal 
energy consumption has declined by almost 24 percent. However, as the Nation's largest single energy user, the Federal Government still spends roughly $\$ 8$ billion each year on the energy required to operate its facilities, vehicles, and industrial equipment. Federal leadership in developing the technical expertise, procurement practices, and financing mechanisms to improve the efficiency of Federal buildings contributes to national energy savings. The establishment of regional, streamlined energy savings performance contracts allows Federal agencies to improve energy efficiency through privatesector investment mechanisms under which initial installation costs are covered by future energy cost savings.

Strategy 2. Provide Federal technical support and leadership in adopting energyefficient and renewable technologies. Procurement mechanisms that enhance Federal agencies' access to 'lean, clean, and green" products can accelerate widespread adoption of newer technologies by providing demonstrations of enhanced performance.

\section{Goal II}

Ensure against energy disruptions protecting our economy from external threat of interrupted supplies or infrastructure failure.

Enhancing the security of global and domestic energy markets is one of the best bulwarks against threats to our Nation's continued economic prosperity. Disruptions in world oil markets have contributed to several economic slowdowns since the early 1970s. Although we have made significant progress toward reducing our vulnerability, there are signs that this vulnerability could increase in the future. The Administration will continue a strong emphasis on emergency preparedness efforts, a renewed emphasis on the stabilization of domestic oil production, and an increased attention to the security of domestic energy systems and related parts of the Nation's critical infra- structure. Actions taken to improve the efficiency with which energy is used will help achieve this goal as well.

Objective 1. Reduce the vulnerability of the U.S. economy to disruptions in oil supply.

Strategy 1. By 2005, stop the decline in domestic oil production. By developing improved reservoir imaging technologies to locate oil in deeper and more complex reservoirs, advanced extraction technologies to boost recovery from mature reservoirs, and environmental technologies to reduce the cost of regulatory compliance, this effort will boost domestic production. Working with industry partners, the effort will develop improved delivery and storage technologies to help ensure a safe, reliable, and cost-effective supply of petroleum products. The Department of Energy will support environmentally responsible development of leased Federal lands for oil recovery. The Department and other Federal agencies will expand collaborative efforts with States to ensure that Administration energy, Federal land management, and environmental policies all adequately protect the environment, but also are consistent and avoid duplicative and unnecessary regulations.

Strategy 2. Maintain readiness to address threats and disruptions to world oil supplies. Working with Congress to maintain the existing Strategic Petroleum Reserve sites and inventory in drawdown-ready condition, together with making investments in drawdown capability, provides a credible deterrent to international oil disruptions and may mitigate economic impacts should such disruptions occur. Investments include completing, by fiscal year 2000, the Life Extension Program to extend the life of this equipment through 2025.

The Strategic Petroleum Reserve is part of a larger effort to coordinate responses to petroleum supply disruptions with U.S. allies through the International Energy Agency. The member countries, at the urging of the United States, have evolved a consensus 


\section{Scanning the Eartb for Oit}

Like doctors using CAT scans to look inside the brain, petroleum geologists use computers and seismic data to look deep within the Earth for Ikely pockets of oil or natural gas. And just as a three-dimensional (3-D) CAT scan inage is assembled from many separale $\mathrm{x}$ rays, $3-\mathrm{D}$ seis mic images assembled fron many seismic snapshots are now a standard tool in the oil industry - one that has made it pos. sible to recover more of the oil in the ground.

Now a new seismic technique is creating a stir. Known as 4-D seismic, it allows petroleum geologists to track the movement of oil or gas over time within a reservoir. The new technique compares several different 3 -D seismic sumeys taken at different times to add a time dimension to the geologic portrait. Developed by a consortium of scientists at Columbia University and five other academic institutions with support from the oil industry and the Department of Energy, the powerful new method can even synthesize seis. mic data that are gathered with different methods or not per. fectly matched.

When the method was ap. plied to the largest oil field in the Gulf of Mexico, near Eugene Island, it showed the drainage of the field over time, except for one intriguing situation. The $4-1$ ) seismic picture showed an area within the reservoir where no depletion was occurring, despite recovery from nearby wells. Sus pecting that the anomaly represented an untapped pocket of oll, the companies drilled a well into it and hit paydirt - an esth mated 2 million barrels of a dditional oil.

The prospect of finding such overlooked pockets, especially in existing ofl fields that already have production facilities in place, is like winning the lot tery, as one expent put it. Use of the 4-1) technque is spreadIng rapidly, the number of oil fields employing it doubling every year Moreover, experts expeet this new seismic tool to increase the amount of U.S. oll and gas ultinately recoverable from the ground by as nuch as 7 to 10 percent boosting do mestic reserves.

Engineering advances also pronise to boost he amount of oil ultimately produced from below. Directional drilling rigs propel the drill bit with a motor inside the plpe itself, deep underground, unlike conventional drill strings propelled from the top, directional driling equipment can turn 90 degree angles or even dril horizontally. New: sensors enable drills to reach a precise location in an oll field even several lilometers from the wellhead.

Even nore futuristic is the equipment being developed to exploit the on industry's last great frontier - sea-floor deposits of oll and gas that lie beneath more than a kilometer of ocean. To get at these deposits, the oil industry is developing remotely controlled robot submarines that operate on the sea floor to install and service wellhead production equipment and indersea pipelines hundreds of kilometers 10ng.

Taken together, these new tools may help to prolong domestic oll and gas production for years to come, helping us to increase domestic oil production and redice US, valnerability to interruptions in imports of foreign oll. agreement that the proper role of governments is to let free markets balance supply and demand for oil in an emergency, and that the governments should supplement supply early in emergencies from strategic reserves. Acting together, the nations of the IEA could inject 4 million to 5 million barrels per day of oil from their reserves into the market while other action is taken to address the cause of the disruption. Efforts should be made to expand IEA membership to broaden the scope of participation.

\section{Strategy 3. Diversify sources of oil available} to world oil markets. By working with in dustry to increase sources of oil available on the world market, the Department of Energy, together with other Federal agencies, can enhance U.S. energy security and global energy security at the same time. Working to open more sources of oil in other regions of the world can reduce the adverse economic impacts that might be brought on by a cut in supply in any one region.

Of particular importance to the expansion of world oil supply sources is the Administration's work in the Caspian and central Asian region, home to large, still-robe-developed reserves of oil and gas. While the actual extent of Caspian region oil and gas reserves (excluding Russia and Iran) is not yet definitely known, most observers believe the region could hold oil reserves in the range of 100 billion to 200 billion barrels and gas reserves of 300 trillion to 600 trillion cubic feet. The Administration is working to encourage the countries of that region to adopt open, fair, and transparent investment regimes that will create a favorable climate for U.S. companies to participate directly in the development of the region's energy resources. The Administration is also working with the countries of the region to develop multiple transportation options for moving the region's oil production out into world markets.

Currently, more than half of U.S. petroleum imports come from sources within the Western Hemisphere, and the Administration is working to deepen energy coopesation in this area. The Secretary of Energy 
co-chairs, with his Venezuelan counterpart, a Summit of the America's "Regional Energy Cooperation" initiative that opens an important avenue of dialog on energy with our hemispheric neighbors.

Strategy 4. By 2010, develop technology options to belp reduce expected oil consumption by at least 1 million barrels per day. The development of light-duty vehicles with higher fuel economy, new technologies to provide increased production of transportation fuels from biomass and natural gas, increased use of more efficient transportation systems, and improvements in the efficiency of oil use in industrial processes can all help limit the expected growth in oil demand, which otherwise would be supplied by increased oil imports.

Strategy 5. Reduce petroleum use in Federal transportation. Increasing the Federal and postal fleet of alternative-fuel (natural gas, electric, and biofuels) vehicles to 100,000 by 2005 will provide critical support for emerging technologies and spur fueling infrastructure investments for these fuels.

Objective 2. Ensure energy system reliability, flexibility, and emergency response capability.

Strategy 1. Promote the reliability and flexibility of electricity generation, transmission, and distribution. Highly reliable electricity supply systems are vital to our national security, the well-being of our economy, and the quality of life in an era marked by increasing technological sophistication. Reliability and competition in the electricity industry can be compatible, but this result will not be achieved automatically; it must be made a design requirement for the public and private officials responsible for the architecture of the new industry.

Accordingly, as part of the Administration's Comprehensive Electricity Competition Plan [see box on page 11], reliability standards would be established and enforced by industry subject to the oversight of the Federal Energy Regulatory Commission.
Strategy 2. Promote the reliability and flexibility of domestic oil refining, transportation, and storage. Flexible implementation of new air emission regulations, together with expanded R\&D support for lowemission refinery technologies, can help lower the cost of full environmental compliance, thereby minimizing adverse impacts on the domestic refining industry. The Department of Energy will work with industry and government regulators to meet increasingly stringent emission regulations more cost-effectively, while meeting increased demands for lighter, high-value finished petroleum products. Specific research efforts will address the new ozone/PM 2.5 standards; process modifications or technology improvements in refineries to prevent the formations of pollutants; use of ceramic membranes to separate high-value hydrogen from low-value refinery gases to improve product quality; and biochemical processes to upgrade crude oil. Further, in cooperation with the President's Commission on Critical Infrastructure Protection (PCCIP) and other Federal agencies, the Department of Energy will determine the best approach to enhance the security of the domestic oil refining, transport, and storage infrastructure. The PCCIP effort represents the first coordinated, interagency effort to protect the Nation's critical infrastructure.

Strategy 3. Promote the reliability and flexibility of natural gas transportation and storage. This effort will reduce the costs and increase the deliverability of the Nation's storage and delivery system to meet the projected growth in natural gas demand. Working closely with industry, the effort will develop novel and advanced fracture simulation technologies and improved remediation treatments that will increase reservoir deliverability. $R \& D$ in improved gasflow metering and energy-measurement technologies will provide real-time, automated monitoring of pipeline gas flow and energy content, maximizing system capacity and gas sales to customers. The effort will develop advanced storage technologies to meet the specific storage needs of new 
and growing industrial and power generation markets, specifically the short-term or hourly requirements of the power generation sector. Research in emission-detection technologies will lead to development of systems capable of covering larger areas more cost-effectively and with greater accuracy than current technologies. Lastly, the PCCIP effort will determine the best approach to enhance the security of the domestic natural gas production, transport, and storage infrastructure.

\section{Goal III}

Promote energy production and use in ways that respect health and environmental values - improving our health and local, regional, and global environmental quality.

Climate change and other environmental issues present difficult challenges for the energy sector. U.S. demand for energy, especially for clean and reasonably priced energy sources, is likely to grow over time. New Clean Air Act requirements will impose additional requirements and costs. Abiding by the Kyoto Protocol will require the United States to make significant changes in energy use to reduce greenhouse gas emissions. Substantial improvements in energy technology and flexible, market-oriented government policies will help grow the economy while meeting our environmental goals. [See Appendix A for a discussion of the Kyoto Protocol.]

Objective 1. Increase domestic energy production in an environmentally responsible manner.

Strategy 1. Support policies to allow domestic natural gas supply to grow by as much as 6 trillion cubic feet by 2010. About 60 percent of this growth will be used in electricity-generating systems. Natural gas technologies are the most economic fossil fuel-based technologies for new capacity in electricity generation. By developing improved reservoir-imaging technologies to locate natural gas in deeper and more complex reservoirs, developing the drilling technology needed to reach those reservoirs, researching advanced extraction techniques to boost recovery from mature reservoirs, and leading industry in developing technologies that can reduce the cost of environmental compliance, domestic natural gas production can be significantly boosted. The Department of Energy will support environmentally responsible development of leased Federal lands for natural gas recovery. Lastly, the Department and other Federal agenc.es will expand collaborative efforts with States to ensure that Administration energy, Federal land management, and environmental policies all adequately protect the environment, but also are consistent and avoid cuplicative and unnecessary regulations.

Strategy 2. Use advanced technologies to recover more oil from reservoirs without significant environmental degradation. The development and use of advanced exploration and recovery technologies can result in more than 400 million barrels of additional cumulative oil production between now and 2005. Working closely with industry, this effort will foster the more widespread use by industry of "best management practices" for environmental protection. Advanced technologies will be developed to lower the cost of drilling and production waste management, detection and control of air emissions, treatment and disposal of produced water, and management of naturally occurring radioactive materials. Credible scientific and technical information will be developed to serve as the basis for regulatory and compliance strategies. The Department of Energy and other Federal agencies will expand collaborative efforts with States to ensure that the Administration's energy, Federal land, and environmental policies are consistent and to eliminate duplicative and unnecessary regulations. 
Strategy 3. Develop renewable electric energy technologies capable of economically doubling nonbydroelectric renewable generation capacity to a total of at least 25,000 megawatts by the year 2010, and maintain the viability of existing bydropower sources. Expanded Federal R\&D efforts in renewable energy sources would encourage renewable energy. Voluntary, cost-shared partnerships with the Nation's utilities, industries, States, and the public will advance development and deployment of clean, renewable energy technologies. Improvements in the efficiency and affordability of renewable energy sources (such as wind energy, photovoltaics, solar thermal, geothermal, and biomass) will make clean, cost-effective, and reliable energy options more attractive in a competitive market, while also adding to the diversity of the Nation's energy supply. Technologies such as electric energy storage can increase the applicability of these renewable energy sources. Extension of the wind and biomass tax credit, which is part of the President's proposed tax package, will promote further acceptance and use of these renewable technologies [see Appendix B]. In addition, the Administration's Comprehensive Electricity Competition Plan includes a requirement that a specified percentage of electricity sales be from non-hydropower renewable sources.

The development of advanced hydropower turbines to repower existing dams has the potential to avoid some of the environmental challenges posed by conventional hydropower plants and extend the life of existing hydropower plants to help preserve their contribution to U.S. energy production.

The installation of photovoltaics and solar water heating systems on rooftops also will contribute to this strategy. Photovoltaic systems, including those that are incorporated into roofing materials, supply electricity directly to homes and other buildings and offer a clean and renewable source of electricity for the Nation. Solar water and air heating systems are equally attractive renewable energy options. To ensure that rooftop solar systems gain more widespread use in the market, the President has proposed a 15-percent tax credit for the purchase of such equipment [see Appendix B]. The Federal Government will work in partnership with utilities, builders, solar equipment manufacturers, State agencies, cities, and financial institutions to help meet the President's goal of installing 1 million photovoltaic and solar water and air heating systems on the roofs of buildings and homes across the Nation by 2010 . The Federal Government will take the lead by installing 20,000 solar rooftop systems on its own facilities by 2010 .

Strategy 4. Maintain a viable nuclear energy option. Cooperation between the private and public sectors to avoid premature shutdown of viable existing nuclear powerplants and R\&D into nuclear power technology improvements can reduce greenhouse gas and other emissions from the electricity-generating sector. Nuclear power is an essential element in the overall energy supply mix of the United States and the world. An important issue impeding its progress is the disposal of nuclear waste.

The Nuclear Waste Policy Act of 1982 (Public Law 97-425) established the Department of Energy's responsibility to provide for the permanent disposal of the Nation's high-level radioactive waste and spent nuclear fuel and directed that the owners and generators of these wastes bear the costs of their management and disposal. The current program focuses on completing the scientific and technical analyses of the Yucca Mountain site, and if it is determined to be suitable for a geologic repository, obtaining a license from the Nuclear Regulatory Commission.

\section{Objective 2. Accelerate the development and market adoption of environmentally friendly technologies.}

Strategy 1. Increase efforts to deploy climate-friendly technologies in the near term. The President's fiscal year 1999 budget includes a $\$ 6.3$ billion, 5-year plan to stimulate the adoption of climate-friendly technologies through a combination of increased investments in research, development, and 
early deployment programs, plus tax incentives for climate-beneficial investments. [See Appendix B for a discussion of the President's proposal.] This will accelerate the diffusion and market adoption of new and existing technologies in ways that generate economic benefits while reducing greenhouse gases and other emissions.

Accelerated development of biomass liquid fuels technologies, along with new voluntary programs that foster rapid adoption of alternative-fuel vehicles, could displace 100 million barrels of oil per year by 2005 and reduce expected energy consumption in the industrial sector by as much as 2 percent by 2010. Liquid fuels produced from biomass crops and agricultural residues provide a clean, affordable alternative to oil consumption in the transportation sector.

Promoting the acquisition of newly developed alternative-fuel transportation technologies for government and private fleets, through efforts such as the Clean Cities program, encourages more widespread use of alternative fuels. Federal funding, leveraged by significant private investment, can create an infrastructure of corridors in which alternative-fuel vehicles can readily find refueling stations, spurring the use of alternative transportation fuels in key regions.

Biomass energy systems for electricity generation, such as systems for co-firing energy crops with coal or for gasifying energy crops, potentially provide a clean, renewable alternative energy source. Since bioenergy crops raised for biomass energy systems absorb carbon during growth, their use for transportation fuels or electricity generation can, in principle, yield little, if any, net carbon dioxide over their life cycle. Displacing conventional fuels with biomass fuels can thus substantially lower greenhouse gas emissions.

\section{Strategy 2. Initiate sectoral consultations with U.S. industry to promote expanded vol- untary efforts to reduce greenbouse gas emis- sions. The Administration will seek voluntary pledges from major energy-using industries to reduce greenhouse gas emissions, ex-}

panding on successful programs in the electric utility sector and other industries. The Administration will ensure that those who take early action will receive appropriate credit for their actions. In addition, this environmental leadership will be afforded public recognition to help establish an example for others to emulate.

Strategy 3. Design a domestic greenbouse gas emission trading system that will help meet binding emission targets in the most cost-effective way. Domestic emission targets likely will be met, in part, through a system of emission allowance trading that builds upon the successful experience in reducing emissions associated with acid rain. A greenhouse gas emission trading system, however, will be more complex and will require substantial analytical development for effective implementation. This development will be carried out by an interagency team with substantial input from the private sector.

Strategy 4. Participate in discussions unith developing countries regarding their commitments to reduce greenhouse gas emissions, primarily tbrough climate-friendly technologies. An international response to reduce greenhouse gas emissions will be most effective if it includes the participation of key developing countries whose emissions are large and rapidly growing. The President has stated that the Administration would make submission of the Kyoto Protocol for Serate advice and consent to ratification contingent on the meaningful participation of key developing countries.

The Administration is developing a diplomatic strategy to engage key developing countries in a dialog that is intended to lead to some of these countries taking on more meaningful climate-change commitments. The Administration expects to engage in bilateral and multilateral discussions through various forums leading up to the Fourth Conference of the Parties in Buenos Aires in November 1998. [See Appendix A for further information on the Kyoto Protocol.] 
Strategy 5. Promote international joint efforts to reduce greenbouse gas emissions. The development of a viable international emission allowance trading system among developed countries and the expansion of efforts to allow firms in developed countries to engage in emission reductions in developing countries while receiving credits for these reductions are critical elements of a globally cost-effective response to climate change. The Kyoto agreement provides for a system of international trade in emission permits, but does not specify all the details of such a system. The provisions that remain to be specified include monitoring and reporting practices, methods of recordation and reporting of trades, and compliance matters.

Further specification is also needed on procedures for banking unused credits, for bringing additional Parties into the agreement, and for recognizing emission reductions before the start of the first budget period.

It is widely believed that international trading of greenhouse gas permits could bring a wide range of low-cost carbon reduction opportunities to U.S. industries and significantly reduce the cost of U.S. emission reductions.

\section{Goal IV}

Expand future energy choices - pursuing continued progress in science and technology to provide future generations with a robust portfolio of clean and reasonably priced energy sources.

The U.S. scientific enterprise is the largest and most successful in the world. Advances in science and technology are critical to achieving our Nation's economic, environmental, and security objectives. Because competitive markets tend to underinvest in critical research and development for longterm energy solutions, government $R \& D$ investments - often in collaboration with the private sector - are needed to help ensure a steady stream of innovation that benefits the Nation and the world with improved energy technologies.
Objective 1. Maintain a strong national knowledge base as the foundation for informed energy decisions, new energy systems, and enabling technologies of the future.

Strategy 1. Develop science that supports decisionmaking on future energy options, including the requirements of new energy system concepts and their anticipated effects on buman bealth and the physical environment. Energy production and use can result in releases of chemicals, particles, radiation, and other substances into the environment. Improved understanding of energy-related pollution (its generation, transport, interaction, and transformation pathways), as well as development of validated scientific models and methods for analyzing and predicting the health and environmental consequences of alternative energy options, will assist the Federal Government and the private sector in making informed energy investment choices. In addition, computational and highspeed simulation tools are needed to analyze the performance of new energy systems and the effects of modifying existing energy systems. These tools will reduce the need for costly test and pilot-scale facilities.

Strategy 2. Intensify basic researcb on global climate change and on long-term, innovative systems for carbon cycle management. Research into new technologies to capture and sequester energy-related carbon emissions could greatly expand the portfolio of long-term technology options available to manage the relationship between energy use and greenhouse gas emissions.

Predicting and assessing the specific effects of greenhouse gas emissions and aerosols (small particles produced by fossil fuel combustion that reflect solar radiation) on climate will require improved understanding of the natural processes affecting climate and of the ways human activities alter these processes. Basic research on natural carbon sequestration will advance understanding of the flow of carbon between the atmosphere, biosphere, and oceans. Research in these topics will identify the natural cycles and 


\section{Storing Carbon Naturally}

Concem that tarth's clmate may be changing has focused attention on emissions of carbon di oxide and other greenhouse gases arising from human activities. But those emissions are only part of the story. Trees and other plants absorb carbon dioxide solls sometimes emit it, and oceans do both. These flows, part of Earths natural carbon cycle, are 10 times larger than industrial emissions. Could forests be managed in ways that enhance the storage of carbon, helping to offset human activities and hence to stabilize the climate?

Ten years ago, not enough was known about the dynamics of forests to answer such questions. But a flurry of research, and in particular new methods of making direct measurements of how much carbon dioxide forests capture from the atmosphere, has begun to provide some insights. And the Kyoto Protocol provides ample incentive to probe further, because it offers emission credits to coun tries lhat can either plant new forests of "sequester" additional carbon in existing forests.

Planting new forests to re place those cut seems straightforward. But which lands and what species of trees will cap ture and store away the most carbon? And which will offer the most additional benefits - as a source of commercial timber, as improved wildife habitat or watershed protection, as recreational opportunity? Studies now under way, such as the hardnood seedlings planted on a plot of frequently flooded land by scientists from Louisiana Tech University, are seeking answers. In the Mississippi River Valley alone, there are more wan 4 million acres that not long ago held botton land forests, much of it now abandoned bean fields and other excess agricultural land.

Managing forests to maximize carbon siorage is nore complex Planting quick-growing trees and harvesting them for lumber on short cycles, every 30 years or so, might seem like an obvious approach, The carbon in wood, after all, is often stored as lum ber in buildings or as paper in libraties for decades. But when forests are cut, carbon stored in the soil as roots and other organic matter begins to decay, releasing large amounts of carbon dioxide. Might different management practices ncrease carbon sequestration? More research is needed. but recent studies show that even mature forests more than 200 years old are vigorously taking up carbon, suggesting that very long cycles may be better. For estry management practices could make a big difference in how much carbon can be sequestered.

Still other approaches that might enhance carbon storage remain to be explored. Would fertlizing forests help? Or how about geneticaly engineering trees to store more carbon in the wood and less in the roots? Might additional research find ways to increase microbial production of humus in the soil and to protect it better from decomposition which could enormously increase the storage of carbon in solls?

A changing climate itself could become a najor factor Longer growing seasons, more rain, and higher levels of carbon dioxide - a nutrient for trees - in the atmosphere could stimulate growth and carbon storage, at least in mid-latitude forests, for many decades. In high-latitude peat and permatrost forests, on the other hand, there is sugges tive evidence that higher temperatures will unlock large stores of carbon in the soil, resulting in additional emissions to the atmosphere.

There is still much to do to fully understand Earth's natural carbon cycle. But because forests might help restore that cycle to balance by capturing a portion of the carbon released by human activities, as much as 30 percent in some estimates, developing such a strategy further seems a high priority for research. human intervention opportunities that could lead to cost-effective approaches to sequestering carbon emissions. The underlying science will contribute to U.S. leadership in the development of new technologies.

Strategy 3. Conduct basic research that provides the foundations for long-term energytechnology breaktbroughs. This strategy supports high-priority research in energyrelated sciences while improving mechanisms that support multidisciplinary research.

We must develop and maintain a besic research investment portfolio that ensures a competitive U.S. position in those areas of the natural sciences and engineering that are relevant to energy resources, production, conversion, and efficiency and to the mitigation of the adverse impacts of energy production and use. These sciences include materials sciences, chemical sciences, nuclear sciences, energy biosciences, structural biological and environmental sciences, genomic sciences, computational and mathematical sciences, engineering sciences, geosciences, and fusion and fusion plasma sciences. Efforts will focus on developing this national investment portfolio with a fuller understanding of the diverse research contributions by government, academia, and industry. This will require expanding research partnerships to increase the leverage of our national science investments.

Strategy 4. Support a strong energy science infrastructure. To conduct energy research in the national interest, the Nation's scientists in government, industry, and acadernia must have access to modern, leading-edge research facilities, including major scientific user facilities and the Nation's laboratories.

We should maintain and operate premier national user facilities to serve researchers at universities, national laboratories, and industrial laboratories, thus enabling the acquisition of new knowledge. Improving access to these user facilities, both onsite and remotely, by all qualified researchers will foster research partnerships between the public and private sectors. 
Integral to a strong energy science infrastructure is improved cooperation among government, academia, and industry to promote the energy, math, and science awareness that will enable advanced education opportunities and build institutional capacity for important research. Cooperative efforts will be undertaken to expand the range of scientific and technical materials to educators and students, improve general math and science awareness, and help cultivate the next generation of world-class U.S. scientists and engineers.

\section{Objective 2. Develop technologies that expand long-term energy options.}

Strategy 1. Develop long-term energy technologies that increase energy options, improve overall economics, use resources more efficiently, and reduce adverse impacts of energy supply and use. This includes the development of advanced renewable technologies, research into fusion and low-cost proliferation-resistant nuclear fission reactor technologies, assessing the development of large, unconventional sources of methane (such as methane hydrate), and development of technologies for the storage, distribution, and conversion of hydrogen.

Fusion energy has the potential to provide an economically and environmentally attractive long-term option. Understanding the physics of ignited, or self-heated, plasmas and developing the technologies essential for fusion energy are linked goals that are achievable through the cooperative efforts of the world community.

\section{Goal V}

Cooperate internationally on global issues - developing the means to address global economic, security, and environmental concerns.

The energy market is now a global market. How effectively the United States interacts on an international basis will, to a large extent, determine how economically prosperous we remain domestically. Coopera-

\section{Putting Superconductivity to Work}

The discovery, in 1986 , electrified physicists around the world: superconductivity at temperatures high enough that the phenom enon night become nore than a laboratory curiosity A decade later, explaining that phenonenon theoretically remains perhaps the preeninent unsolved problem of condensed matter plusics.

Yet despite such unknowns, there has been remarkable progress loward practical applcations. In 1997 , industry nanufactured nore than 200 kilometers of supercondueting wire, under ground superconducting transmis sion lines for electric power. especially in urban areas, seem likely to be a commercial realiv within a few years, with other energy-related uses close behind.

To reach this point has required the cooperation of univer sity, government, and industrial screntsts in a remarkable sy mbio. sis of basic and applied research High-temperature saperconduc tors are ceramics, brittle nateri als that at first seemed impossible to form into wires ar all. But a solution was found by packing su perconduching powder in siver tubes and then processing the tube into wire. Since 1993, elec trical devices have been built and lested using these powder in lube' wires. More recently, re searchers have found that thin films of high-temperature superconducting materials deposited on a metal strip were much more flexible- a discovery that opened up new approaches to making superconducting wire. Today, the powder-in-tube approach still dominates, but thinfilm processes for making wires continue to evolve.

Even so, many prototype wires initially could not carry large currents, because of internal defects caused by disordered crystalline segments, or "grains, within the material, But scientists with years of experience in netal processing, knowing that thin films often copy the internal patterns of the naterial they form on, suggested a way around the difficulty. They pointed out that rolling the underlying metal strip would align its grains, potentially creating an ideal template for the superconducting material and so it turned out Current densities im proved.

The dialog between fundamen tal studies and practical development has continued. To understand complex superconducting materials better, scientists have studied their structure, seeking clues to their properties. That required collecting data with neutron beams, fat more sensitive than $\mathrm{x}$ rays when probing light elements, such as the oxygen that is a critical constituent of these still mysterious new materials. It also required exploring how these materials behave in strong magnetic fields - since such fields can stop superconducting behavior Insights from this research feeds develophent of improved wire manufacturing processes and industry teams working on applications for superconducting wire-transmission lines, large notors, transformers, energy storage devices with superconducting bearings. The payoff is expected to be substantial - protolypes are being developed of virtually lossfree transmission lines and highcapacity uncerground cables, nore efficient electric notors that are balf the size of conventional units, and devices that could store 1arge amounts of electric power relatively cheaply.

There still are more problems to solve before a full range of superconducting technologies can be commerctalized. More power ful research tools are being developed by Department of Energy laboratories - a more intense neutron beam at Oal Ridge National laboratory, equipment that can generate very strong magnetic fields at los Alamos National Laboratory Industry teams are gearing up to make even larger quantities of superconducting wire But the electric power incustry has begun to assent that, eatly in the 21 st century superconductivity will emerge fron the laboratory and add to lie Nation's energy options. 
tion with foreign governments on energy regulations and laws, promotion and deployment of clean and efficient energy systems worldwide, and international science and technology cooperation aimed at maximizing benefits from Federal R\&D funds will be important in determining how well we succeed in achieving our energy, economic, and environmental goals and objectives. The responsible transfer of energy technologies will also play an important role in international cooperative activities. International cooperation and collaboration will also be needed to address global environmental issues such as climate change.

Objective 1. Promote development of open, competitive international energy markets, and facilitate the adoption of clean, safe, and efficient energy systems.

Strategy 1. Cooperate with foreign governments and international institutions to develop energy-sector laws, policies, and regulatory processes for setting standards and enforcing regulations. This strategy emphasizes the development and implementation of appropriate policies and regulations through active and sustained participation in multilateral international and regional forums, and through constructive bilateral engagement with key countries. The United States is currently an active participant in the International Energy Agency, the International Atomic Energy Agency, the Nuclear Energy Agency, Asia Pacific Economic Cooperation (APEC), the Summit of the Americas, the G-8 Summit, and other multilateral groups. In addition, new regional forums with important energy programs (such as the Southeast Europe Cooperation Initiative) are emerging that offer new opportunities for leadership.

Working with our neighbors in Mexico and Canada, the Administration hopes to develop cooperative agreements among regulatory bodies to promote a North American natural gas and electricity system that is reliable, nondiscriminatory, and responsive to the marketplace. In the case of natural gas, free trade exists between Canada and the United States, and most regulatory differ- ences have been resolved. Mexico is committed to creating an open-market system, but some obstacles still exist. In the case of electricity, all three countries are considering and making changes in their respective electric power sectors.

Strategy 2. Promote deployment of clean and efficient energy systems. By promoting the export of clean, energy-efficient, and cost-effective technologies through partnerships with energy industries, trade associations, and multilateral agencies, the Federal Government can help private industry identify hundreds of millions of dollars in market opportunities each year. International demand for electricity is expected to grow substantially in coming decades, with high demand for distributed non-grid-connected renewable energy applications. By gaining a substantial share of international markets, U.S. industries can reduce the costs of clean energy technologies.

Strategy 3. Promote international science and tecbnology collaboration to avoid duplication and maximize the national benefits of Federal RED efforts. International cooperation is, and will continue to be, a vital part of our Nation's science and technology programs. It is essential to our ability to participate in, for example, large-scale experiments and to advance the goals of our science and energy programs.

Participation in international collaborations allows the United States to develop and promote clean, safe, and efficient energy technologies, remain a leader in basic energy research, and promote U.S. national security objectives. There are many ongoing collaborations in science and energyrelated fields. These include the Russian-American Fuel Cell Consortium; the International Thermonuclear Experimental Reactor Project with the European Union, Japan, and the Russian Federation; the Large Hadron Collider program collaboration with the European Physics Laboratory (CERN); and the Next Generation Internet (NGI) project, which will connect thousands of teams of researchers spread across the world. NGI is especially critical for international col- 
laborations, where large, complex multidisciplinary problems require transfer of massive amounts of data in reasonable periods of time.

\section{Objective 2. Promote foreign regional stability by reducing energy-related en- vironmental risks in areas of U.S. secu- rity interest.}

Strategy 1. Promote foreign capacity building and solutions to environmental security concerns, integrating the capabilities of the Department of Energy and otber agencies, foreign governments, the private sector, and nongovernmental organizations. Identifying, assessing, and prioritizing environmental security concerns in selected world regions of importance to the United States will help point to cost-effective solutions to potential threats to U.S. national security interests. Environmental threats that cross national boundaries around the world can have a profound impact on the national security interests of the United States. Recognition of this reality has enlarged the focus of U.S. foreign policy to embrace international environmental issues, and has spurred new initiatives to prevent and remediate environmental degradation.

The Federal Government expects to address environmental security issues in partnership with the private sector and other donor governments, as well as with foreign, host governments. Areas of likely progress include the safe handling and disposition of nuclear materials, short- and long-term environmental management, energy resource development, demand-side management and efficiency, and modeling and assessments.

\section{A Shared Commitment}

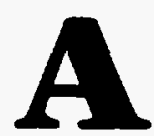

broad consensus on overarching energy policy goals does not ensure achievement of better energy and environmental outcomes. The vast array of participants in energy markets - the private sector, nations and their government agencies, public and private research facilities, advocacy groups, and individual citizens - have differing and perhaps changing perspectives on their roles and actions, even if they agree on the broad goals. Even if the entire choir has the same songbook, harmony will not result if everyone is singing from a different page. A fundamental challenge facing the United States is to harmonize these potentially discordant interests into making shared contributions to meeting the shared objectives.

The goals of the Comprehensive National Energy Strategy require a shared commitment if they are to be achieved. The various Federal agencies need to cooperate and coordinate activities in pursuit of these goals, with involvement at all levels and by making use of the unparalleled resources of the national laboratories. Similarly, the several branches of government must share in the belief that pursuit of these goals is a priority when resource commitments are being made. The commitment must extend beyond government to the private sector, which will be engaged through public-private partnerships, based on the recognition that meeting these goals is in the long-term interest of everyone involved. The nonprofit sector, especially universities, also must make a commitment to pursue these goals in order to mobilize the unique resources contained in these institutions. Communities also must share in the commitment, for the benefits of meeting these goals extend far beyond any single business or individual. Finally, countries must share in the commitment, for many of the benefits are global in nature, and the resources and knowledge base to address these goals generally are not concentrated solely in the United States. These shared commitments will maximize the probability of being successful without devoting unreasonable amounts of resources to this effort. If success is achieved, we will leave future generations of Americans a more livable country and a thriving energy sector with a wide variety of affordable and safe energy alternatives. 



\section{Appendixes}

Appendix A. The Kyoto Protocol on Climate Change .

Appendix B. The President's Climate Change Technology Initiative

33 


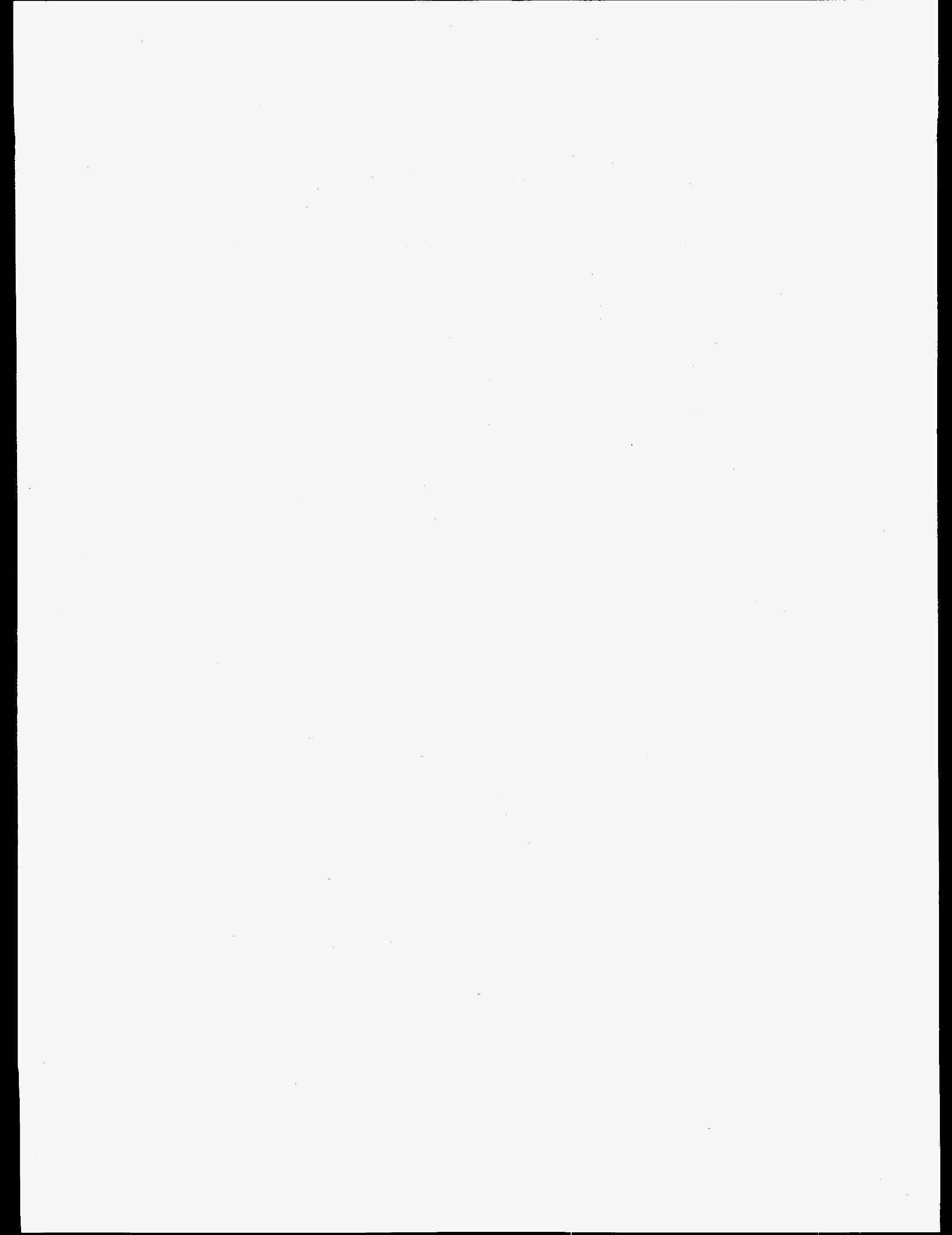




\section{Appendix A: The Kyoto Protocol on Climate Change}

At a conference held December 1-11, 1997, in Kyoto, Japan, the Parties to the United Nations Framework Convention on Climate Change agreed to a historic protocol to reduce greenhouse gas emissions by harnessing the forces of the global marketplace to protect the environment. The Kyoto Protocol makes a down payment on the meaningful participation of developing countries, but more needs to be done in this area. Securing the meaningful participation of developing countries remains a core U.S. goal.

\section{Emission Targets}

A central feature of the Kyoto Protocol is a set of binding emission targets for developed nations. The specific limits vary from country to country, though those for the key industrial powers are similar -8 percent below baseline emissions levels for the European Union, 6 percent for Japan, and 7 percent for the United States.

Emission targets are to be reached over a five-year budget period as proposed by the United States, rather than by a single year. The first commitment period will be the U.S. proposal of 2008-2012. The emission targets include all six major greenhouse gases. (More precisely, the U.S. reduction called for is 7 percent below a baseline of 1990 levels for the bulk of emissions and 1995 levels for three synthetic greenhouse gases.) Some activities that absorb carbon, such as planting trees, will be offset against emission targets.

\section{International Emission Trading}

Under an emission trading regime, countries or companies can purchase emission permits from countries that have more permits than they need (because they have met their targets with room to spare). This free-market approach, pioneered in the United States, will allow countries to seek out the most economical emission reductions, substantially lowering costs for the United States and others. Structured effectively, emission trading can provide a powerful economic incentive to cut emissions while also allowing important flexibility for taking costeffective actions.

The inclusion of emission trading in the Kyoto Protocol reflects an important decision to address climate change through the flexibility of market mechanisms. Led by the United States, the Conference rejected proposals to require all Parties with targets to impose specific mandatory measures, such as energy taxes.

\section{Joint Implementation Among Developed Countries}

Countries with emission targets may get credit toward their targets through 
project-based emission reductions in other such countries. The private sector may participate in these activities.

\section{Clean Development Mechanism}

The Clean Development Mechanism will allow companies in the developed world to enter into cooperative projects to reduce emissions in the developing world - such as the construction of high-tech, environmentally sound powerplants - for the benefit of both parties. The companies will be able to reduce emissions at lower costs than they could at home, while developing countries will be able to receive the kind of technology that can allow them to grow more sustainably. The Clean Development Mechanism will certify and score projects, and it can also allow developing countries to bring projects forward in circumstances where there is no immediate developed country partner. Under the Clean Development Mechanism, companies can choose to make investments in projects or to buy emission reductions. In addition, Parties will ensure that a small portion of proceeds is used to help particularly vulnerable developing countries, such as island states, adapt to the environmental consequences of climate change and to cover administrative expenses for the operation of the mechanism.

With the Clean Development Mechanism, developed countries will be able to use certified emission reductions from project activities in developing countries to contribute to their compliance with greenhouse gas reduction targets. Importantly, certified emission reductions achieved starting in the year 2000 can count toward compliance with the first budget period. This means that private companies in the developed world will be able to benefit from taking early action.

\section{Developing Countries}

Various provisions of the Kyoto Protocol, taken together, represent a down payment on developing countries' participation in e:fforts to reduce greenhouse gas emissions. The Clean Development Mechanism represents one way developing countries will be engaged, as outlined above.

In addition, the protocol also advances the implementation by all Parties of their commitments under the 1992 Framework Convention on Climate Change. For example, the protocol identifies various sectors (including energy, transport, and industry as well as agriculture, forestry, and waste management) in which actions should be considered in developing national programs to combat climate change and provides for more specific reporting on actions taken.

Securing meaningful participation from key developing countries remains a priority for the United States. The Administration has stated that without such participation, it will not submit the Kyoto Protocol to the United States Senate for advice and consent to ratification.

\section{Meeting the Emission Reduction Goal}

A global solution is critical to the global threat of climate change. This Administration pursues the most efficient approach to reduce global greenhouse gas emissions. The nature of the climate change problem suggests three basic methods to lower costs of achieving given levels of environmental protection. They can be characterized in terms of three categories of flexibility: (1) "when" flexibility; (2) "what" flexibility; and (3) "where" flexibility, which may be the most important of all. Such methods have long been championed by economists interested in increasing the efficiency of protection. Economic studies have found that there are many potential policies to reduce greenhouse gas emissions for which the benefits outweigh the costs. The most efficient approach to slowing climate change is through market-based policies.

According to a Council of Economic Advisers analysis, the costs of greenhouse 
gas emission reductions called for under the Kyoto Protocol are not very large (about 0.1 percent of GDP in 2010). Most of the studies that show tremendous impacts on the gross domestic product from imposition of greenhouse gas emission limits ignore the cost-reducing effect of emission trading. They also ignore many benefits likely to re- sult from reducing the threat of climate change. This Administration's policies on $\mathrm{R} \& \mathrm{D}$, tax incentives, and permit trading will provide flexibility to meet the U.S. emission targets. They also will allow markets to respond efficiently to find the least-cost approach in meeting the goals. 



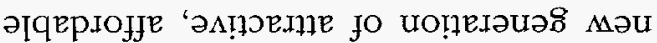

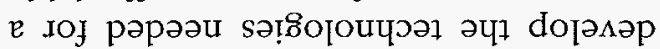

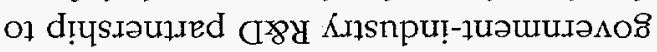

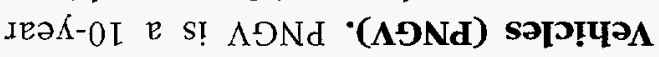

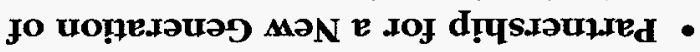

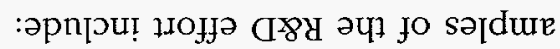

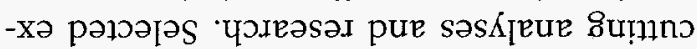
-ssoro pue 'sә!!!!

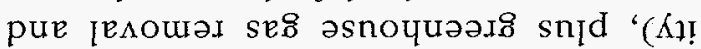

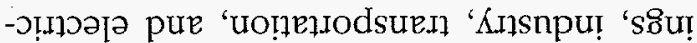

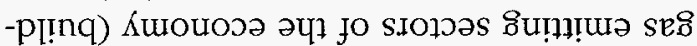

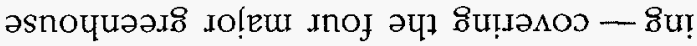

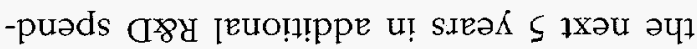
Iว

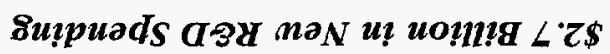

'SUİISÁS JəMOd

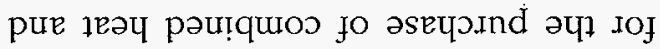

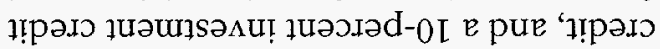

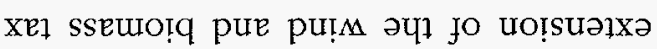

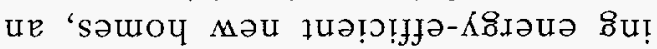

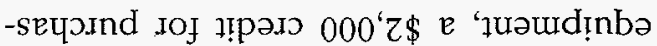

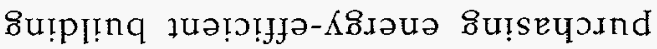

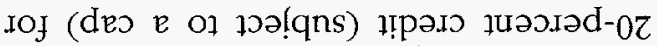
e әpnjou! os[e słno Xe] әपL - Kouว!̣

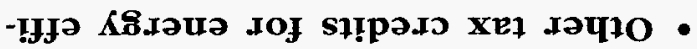
jROB sfooy IRTOS uolt

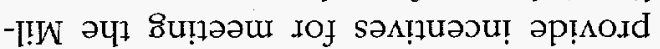

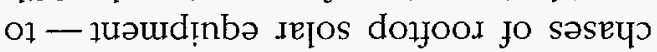

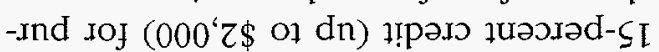

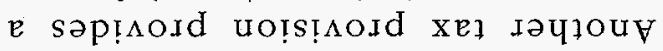
-suəłs

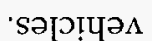

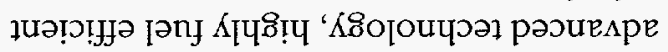

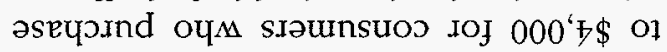

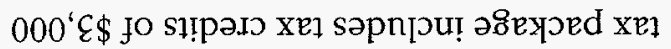

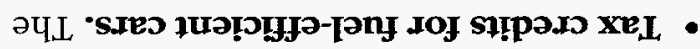

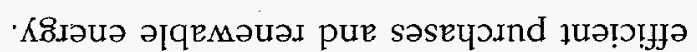

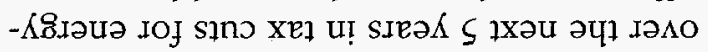

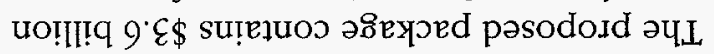

stpad $x y_{L}$ u? uom!g $9 \cdot \mathcal{E} \$$

'SIEəX $\varsigma$

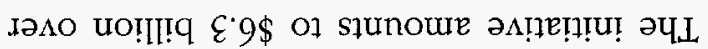

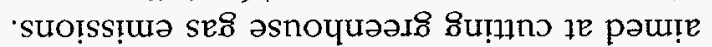

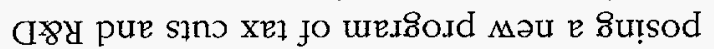

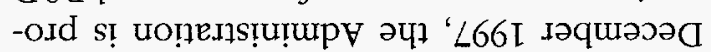

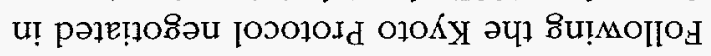

suo!ss!̣ug se⿹ əsnoyuəəIS in $\mathrm{O}_{\mathrm{L}}$

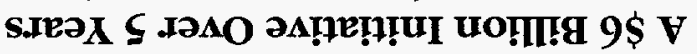

$866 I$ 'LZ KipnupI 'ssauppo uonu

aq1 fo a1płs 'uotull 1119 нuap!saud -

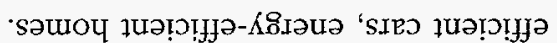

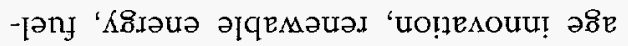

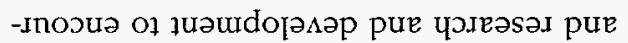

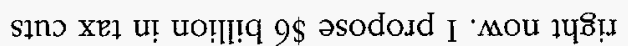

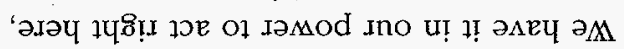

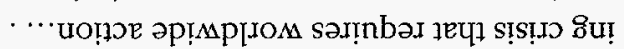

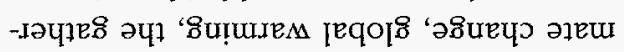
-!р јо шәтqол әр!мрном әч)

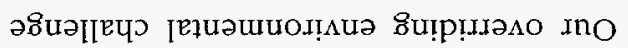


vehicles that can achieve three times the fuel efficiency of 1994 models while meeting all applicable safety and environmental standards. The President's budget request calls for a $\$ 50$-million increase in fiscal year 1999 for PNGV, to \$277 million. Similar joint efforts are proposed to develop more efficient diesel engines for both light and heavy trucks.
- Renewable energy. Expand research partnerships for key renewable technologies such as wind, photovoltaics, geothermal, biomass, and hydropower to accelerate price reductions and improve performance. 


\section{Summary of Public Comments}

\section{Contents}

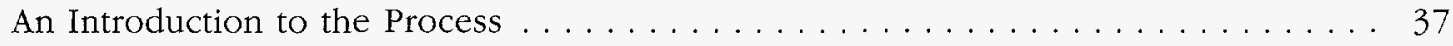

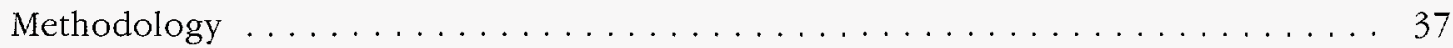

Overarching Themes - Putting a Human Face on Energy Policy . . . . . . . . . . . . 39

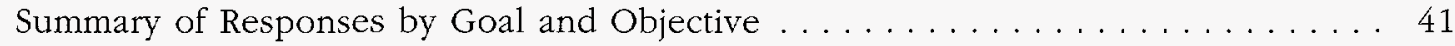

Goal I: Improve the Efficiency of the Energy System . . . . . . . . . . . . 41

Objective 1. Support Competitive and Efficient Electric Systems . . . . . . . . 41

Objective 2. Significantly Increase Energy Efficiency in the

Transportation, Industrial, and Buildings Sectors by $2010 \ldots \ldots \ldots \ldots 45$

Goal II: Ensure Against Energy Disruptions . . . . . . . . . . . . . . . . . 47

Objective 1. Reduce the Vulnerability of the U.S. Economy to Disruptions

in Oil Supply. . . . . . . . . . . . . . . . . . . . 47

Objective 2. Ensure Energy System Reliability, Flexibility, and Emergency

Response Capability . . . . . . . . . . . . . . . . . . . . . . . . 49

Goal III: Promote Energy Production and Use in Ways That Respect

Health and Environmental Values .................... 51

Objective 1. Increase Domestic Energy Production in an Environmentally

Responsible Manner . . . . . . . . . . . . . . . . . . . 51

Objective 2. Accelerate the Development and Market Adoption

of Environmentally Friendly Technologies . . . . . . . . . . . . 52

Goal IV: Expand Future Energy Choices . . . . . . . . . . . . . . . . 54

Objective 1. Maintain a Strong National Knowledge Base as the

Foundation for Informed Energy Decisions, New Energy Systems,

and Enabling Technologies of the Future.............. 54

Objective 2. Develop Technologies That Expand Long-Term Energy

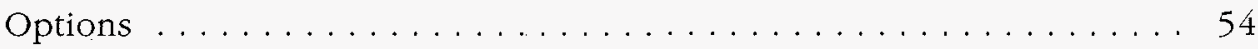

Goal V: Cooperate Internationally on Global Issues . . . . . . . . . . . 55

Objective 1. Promote Development of Open, Competitive International

Energy Markets, and Facilitate the Adoption of Clean, Safe,

and Efficient Energy Systems . . . . . . . . . . . . . . . . 55

Objective 2. Promote Foreign Regional Stability by Reducing

Energy-Related Environmental Risks in Areas of U.S. Security Interest . . 56

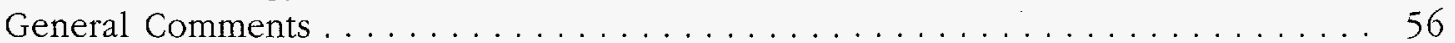

Public Comments Database Summary . . . . . . . . . . . . . . . . 58 


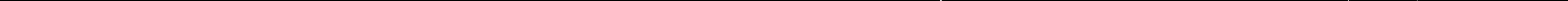




\section{Summary of Public Comments}

\section{An Introduction to the Process}

$\mathbf{T}$

he Comprehensive National Energy

Strategy constitutes the 1998 National

Energy Policy Plan as required by Section 801 of the Department of Energy Organization Act. The Act requires the President to submit a proposed National Energy Policy Plan to Congress and to -

seek the active participation by regional, State, and local agencies and instrumentalities and the private sector through public hearings in cities and rural communities and other appropriate means to insure that the views and proposals of all segments of the economy are taken into account in the formulation and review of such proposed Plan. [42 USC 7321 SEC.801 (A)(2)]

The U.S. Department of Energy (DOE) released a draft Comprehensive National Energy Strategy (CNES) to the public on January 30, 1998. DOE followed the release of this document with three public hearings in cities and rural communities in the United States to provide an overview of the draft CNES by DOE officials and to solicit comments on the draft CNES. ${ }^{1}$ Information on

${ }^{1}$ The Department of Energy convened hearings in Houston, TX, on February 12, 1998; Davis, CA, on February 13, 1998; and Washington, DC, on February 19, 1998. A total of 192 people attended the hearings, and 58 of them spoke.

the dates and venues of the CNES public hearings as well as a solicitation for comments on the draft CNES were made via newspapers, professional and trade newsletters, public notices, and the World Wide Web. DOE received comments on the draft CNES via oral and written testimony, e-mail, fax, and mail. Comments were received during the period from February 1, 1998, to February 27, 1998.

This addendum to the report summarizes the public comments that DOE received in response to the draft CNES.

\section{Methodology}

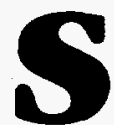
olicitation of comments for the draft CNES was accomplished by posting announcements, notices, and bulletins in various media, including newspapers, professional and trade newsletters, public notices, and the World Wide Web. A notice was published in the Federal Register on January 15, 1998, ${ }^{2}$ announcing public hearings on the CNES. A CNES information page was also posted on the DOE Website on February 5, 1998 (http://www.hr.doe.gov/ nesp/cnes.html). The page included the Federal Register notice, latest information about the hearings, the draft CNES document, and

\footnotetext{
${ }^{2}$ Notice published in Volume 63, Number 10.
} 
several options for sending comments to DOE.

There were 313 comments received during the comment period on the draft CNES, including 29 comments from the Davis, CA, hearing; 19 comments from the Houston, TX, hearing; 35 comments from the Washington, DC, hearing; and 38 by mail or fax, 42 by e-mail, and 150 responses to a response form published on the CNES information page on the DOE Website. The comments collected were compiled into four comprehensive databases, one of which included all of the Website, e-mail, fax, and mail responses, and three separate databases for oral comments received at each of the public hearings. Except for the hearings, the comments in the databases were organized by goals, objectives, and issues, with the options to sort and query for the purposes of statistical analysis and organization.

\section{Public Hearings - Building on Our Commitment to Openness}

Three public hearings were held in Febru ary 1998. At these hearings, DOE invited the public to give oral testimony and to submit written comments. The hearings were chaired and convened by the Secretary, Deputy Secretary, and Undersecretary of Energy. They addressed the need for a proactive energy strategy and distinguished the CNES from previous energy policy plans. Senior DOE officials representing the Offices of Fossil Energy, Energy Research, Energy Efficiency and Renewable Energy, and Policy and International Affairs provided an overview of the draft CNES document. The Chair opened the floor for public comments.

Participants in the public hearings included State and local officials, professors, scientists, researchers, managers, educators, technicians, activists, private citizens, utility representatives, private and commercial industry representatives, public-interest groups, environmental organizations, community action organizations, organized labor, specific technology advocates, and other stakeholders and interested parties.
Of the 313 total CNES respondents, 19 percent provided oral testimony at the three public hearings.

\section{Electronic Responses - Linking the Public With Their Government}

The CNES information page was posted on the DOE Website. It included the draft CNES document, the Federal Register notice, content and logistics information on the hearings, and a comment form (questionnaire).

The Website questionnaire consisted of 12 open-ended questions for soliciting input and general comments on each of the five goals in the CNES document.

Of the 313 respondents, 48 percent provided comments in response to the Internet questionnaire and 13 percent provided comments by e-mail. Of the respondents who indicated how they found out about the Website, 35 percent found out by word of mouth, 16 percent from surfing the Web, 11 percent from professional or trade newsletters, 11 percent from public notices, 2 percent from newspapers and magazines, and 24 percent from other sources. Other sources included personal, group, and bulletin e-mails.

\section{Written Responses}

The participants in the public hearings were asked to fill out questionnaires and submit them at the hearing or to mail or fax hardcopy comments to DOE. General written responses were also submitted by mail and fax in response to the information released on the draft CNES. Written responses submitted at the hearings accounted for 8 percent of all responses. Written resporises submitted by mail or fax accounted for 12 percent of the submissions.

\section{Public Interest in the CNES}

Website respondents were asked, "What portion of the draft CNES interests you most?" The possible responses, corresponding; to the five draft CNES Goals, were:

- Improve the efficiency of the energy system. 
- Ensure against energy disruptions.

- Promote energy production and use in ways that reflect human health and environmental values.

- Expand future energy choices.

- Cooperate internationally on global issues.

- Other.

Approximately 44 percent of the respondents indicated an interest in two or more of the five draft CNES Goals, and about 56 percent focused their interest on a single Goal. Further, only 20 percent selected "Other," indicating an interest in an energy issue not covered by the draft CNES. Also, Website respondents were asked if they would like a response to their comments, and 78 individuals said "yes."

\section{Overarching Themes - Putting a Human Face on Energy Policy}

$\mathbf{I}$ $\mathrm{n}$ reviewing and summarizing the public comments received on the draft CNES, several overarching themes emerged. These were much broader in scope than any of the CNES Goals. These comments reflect fundamental issues and values that respondents believe form the foundation for sound public policy. These overarching themes address questions of ethics, equity, and the role of government.

\section{Etbics}

Ethical considerations were included in many of the comments. These considerations focused on the responsibility incumbent upon Americans to consider the welfare of future generations in current policy decisions. Several comments expressed the notion that the draft CNES is too shortsighted. The "longterm" objectives of the document look only 10 to 20 years into the future. Due to the finite nature of many of our energy resources, it is necessary for sound public policy to consider future generations. Conservation of finite resources and research and development of new technologies to allow future generations access to a variety of energy options was particularly noted as an area of concern.

With no qualifying timeframe, the CNES states that coal, oil, gas, and uranium are abundant in America. This may be true in the near term for some of these fuels, but not for all. Eventually, however, this is not likely to be true for any of them. The latter situation is the basis for conservation of resources beyond our lifetimes that is addressed only by a strong ethical position concerning our responsibilities to future generations far into the future.

- Carl Walter

Further, comments advocated consideration of the environmental impacts of our energy choices. The perceived impacts of these choices included degrading the natural environment and losing valuable genetic resources by destroying habitats in our search for conventional energy sources.

We have to address this energy situation now or the long-term outlook will be a degraded quality of living on the planet... for future generations.

\section{- Thomas J. McGeachen}

Finally, concerns were raised about our ethical obligation to those beyond our borders. These comments centered on the projected exponential population growth and the low standards of living in many areas of the developing world.

\section{Equity}

The concept of equity, while closely tied with ethical considerations, was included in numerous comments. Concern was expressed that energy policy should benefit all Americans, and that the policy instruments and strategies we employ should not have disproportionate adverse effects on any demographic group or region. These concerns about equity included economic, social, and environmental impacts. 
$[\mathrm{H}]$ as CNES missed anything? I think our strategies ... [are] ... missing the people.

\section{- Elena Vergara,}

Cbicano Family Center

Equity was considered to be of paramount importance to many respondents. One even volunteered the following language for a sixth CNES Goal to address the issue:

Ensure the economic and environmental benefits and costs of energy policies are shared equitably (e.g., among different regions, among urban, suburban, and rural environs, between low v. high income and large v. small consumers).

- Thomas C. Adams, III,

North Carolina Department of Commerce

Those concerned about energy equity among the poor, disadvantaged, elderly, underprivileged, and handicapped recommended that the draft CNES include more information about the effects that the proposed energy strategy would have on these groups of "energy-vulnerable citizens." Comments also suggested the adoption of explicit language that recognizes the vulnerability of low-income households to fluctuations in energy costs, as these costs make up a larger proportion of their household expenditures.

Several individuals expressed concern that the interests of the poor are not adequately considered in the draft CNES. Continuation and improvement of Federal and State assistance programs such as weatherization, assistance in paying utility bills, and support for Tribal utilities was advocated by some, while others voiced concern over the continuation of utility-sponsored publicassistance programs in the wake of electricity restructuring.

In addition to these issues of economic equity, concern over the impact of pollution from energy generation was expressed.

\section{Role of Government}

Concerns over the government role in determining energy policy and strategy were included in many comments. Several diverse views were expressed regarding whether there should be an energy policy, who within government should set energy policy priorities, and the types of activities that should be undertaken to implement or encourage these priorities.

Some comments recommended that there should be no energy policy and that market forces should drive energy choices. Other commenters suggested the dissolution of the Department of Energy. Some comments advocated a limited energy policy. These comments favored a role for government that includes establishing fair rules and regulations and letting market forces drive energy choices and policy.

Several comments advocated a more comprehensive approach to energy policy and strategy. Some recommended restructuring the Department of Energy to include only civilian energy programs and relegating all defense-related programs to a separate organization. Others recommended the appointment of an "Energy Czar" to coordinate energy policy across Federal agencies. Finally, others recommended direct intervention in markets and command and control measures to dictate energy policy to the Nation.

No consensus was expressed about who within the Government should determine energy policy. Comments ranged from $s$ upport for significant Federal involvement to State control to local-level decision authority. Some comments even supported energy planning and policy at a global level. Many commenters advocated collaboration among several levels of government to ensure that policy meets the needs of every community.

Those who advocated a Federal role in energy policy expressed divergent views about the types of activities that the Gov- 
ernment should undertake. Some supported central energy planning, while others supported a regulatory role. Many encouraged the Government to act in the "public good," pursuing various objectives like supporting research and development, promoting public education about energy-related issues, and enacting policies to protect citizens. Many comments suggested that the Federal Government and the Department of Energy should lead by example.

The Federal role is to provide long-term support and regulatory consistency so that private investments can be made under a predictable environment.

- James E. Quinn

[The United States should] support research with a $20-50$ year payoff period that will really solve energy, national security, and environmental problems...

- David Hammer

[I]nternational competition has long recognized the importance of government guidance and funding in both general and energy research and development. They are growing in leaps and bounds where we are floundering, especially in regards to new nuclear energy production sites.

- Hamilton T. Hunter

\section{Summary of Responses by Goal and Objective}

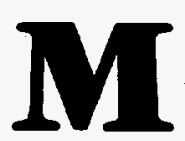

any respondents to DOE's request for comments on the draft CNES addressed specific goals and objectives included in the document. Several comments, however, held implications for multiple goals. To accurately and fairly reflect the comments received, the summary responses have been organized by CNES goal and objective and have been repeated as they apply to each new goal.

Due to the sheer volume of comments received, it was necessary to qualitatively group and summarize issues. This required that the responses be grouped by common theme. Specific recommendations, especially those regarding programmatic decisions and funding levels, have been incorporated thematically in the summary, but are not explicitly stated in this document.

\section{Goal I}

Improve the efficiency of the energy system - making more productive use of energy resources to enhance overall economic performance while protecting the environment and advancing national security.

\section{Objective 1. Support competitive and efficient electric systems.}

Several comments indicated that economic efficiency and energy efficiency are often not the same. It is important, according to these comments, that economic good sense be used in determining the desirable level of energy efficiency. These comments suggested that the CNES should not recommend use of energy-efficiency technologies that are exorbitantly priced and realize only marginal improvements.

[P]ortions of the draft strategy appear to confuse the concept of energy efficiency and that of economic efficiency. The most energy-efficient technology is not necessarily the most economically efficient. This is a matter for markets to sort out, not government.

$$
\text { - Dr. Len Bower }
$$

Deregulation of Electricity. Comments regarding the deregulation and the restructuring of the electric utilities expressed divergent opinions. The key issues raised in this discussion included who should institute reforms, the appropriate type of reforms, and what the impacts of these reforms would be. Most comments on this issue recommended that the Federal Government address deregulation in a cautious and well thought-out manner, considering all of the implications of their actions. Much attention 
was given to the issue of recovering stranded costs and honoring prior agreements.

Advocates of Federal deregulation legislation commented on the need for a firm date by which all restructuring would be completed. Additional comments encouraged DOE to move the Administration to create a comprehensive bill that would ensure reciprocity for electricity suppliers to sell power across State lines.

This pursuit of a fully competitive power market is an absolutely appropriate and timely goal.... Progress will depend on the meaningful actions of the Department. As we all know, a statement in a planning document, no matter how important that document is, is not equivalent to leadership. And leadership is what this issue demands.... If the Administration believes in competition, then it needs to act like it.

\section{- Eugene F. Peters}

Advocates of State-initiated reforms argued that each State must have the latitude to institute reforms on its own time schedule and to the extent that is appropriate for that State. Comments also explicitly declared the need for legislation at the Federal level to grandfather the actions taken already at the State level.

Retail customers should also have the ability to choose among providers and services under restructuring programs developed and implemented at the State level. Accordingly, the Federal Government should afford States the flexibility to determine retail energy policies, including the content, extent, and pace of restructuring.

$$
\begin{array}{r}
\text { - Margaret Welsh, } \\
\text { Executive Director of the } \\
\text { National Association of Regulatory } \\
\text { Utility Commissioners (NARUC) }
\end{array}
$$

The mechanics of restructuring were also a key issue in many of the comments on the draft CNES. Many commenters advocated fully competitive power markets; in contrast, other comments advocated a power market that reflects social values. Proponents of fully open competitive markets raised issues regarding real unbundling of generation and transmission systems and the tax preferences given to municipal power companies through tax-free bonds.

Another commenter noted that the draft CNES probably did not address electric cooperatives for political reasons. The commenter stated that the Federal Government offers low-interest loans to cooperative electric utilities under a rural electrification program that largely completed its mission decades ago.

Some proponents of an open system advocated a fuel-neutral policy that would allow the market to select the fuel mix. They argued that cheap energy is key to our domestic economy. An independent petroleum producer's representative noted that an increase in electricity rates would hurt their production due to electricity's large share of their production costs.

[Making our] energy cheaper and more abundant than any other country's is what will make the difference in keeping the U.S. economically viable.

- George Larson

Other comments advocated a less open approach to deregulation. These comments addressed the need for total cost pricing for fuels and reflecting social values in fuel sources. These advocates of "greerl pricing" supported targeting environmentally friendly technologies in the fuel mix. One commenter from a municipal utility district indicated that, based on a survey of customers, there was support for green pricing even though it marginally tended to increase electricity costs.

Concerns over possible impacts from electricity restructuring included loss of universal service, loss of utility-sponsored public-assistance programs, negative environmental impacts, inequity in cost savings, and decreased system reliability. 
Adequate planning by DOE and others was called for to ensure that deregulation does not undermine the reliability of the U.S. electric power system. Several comments supported the formation of an independent reliability commission. Some comments supported the formation of a "self-regulating reliability organization," while others recommended formation of regional organizations.

Universality of service and equity of savings was raised as another key concern. Many commenters expressed the need for any deregulation legislation to guarantee continued electric service at affordable rates. One commenter indicated that the focus for deregulation should not be on low rates, but on the total bill an individual receives each month for service. With large consumers able to bargain with producers for low rates, individual consumers may bear the burden of higher electric costs.

Allow free market competition, but set baseline requirements that all competing energy providers must meet in order to operate.

\section{- Public Hearings}

The perceived environmental impacts of deregulation were addressed in several comments. With the advent of a cost-driven selection of fuel and generation facilities, several commenters were concerned that there would be an increase in the utilization of older, less environmentally friendly generation facilities. In fact, several comments noted that electricity with the lowest cost per kilowatthour is generated at old coalfired plants, several of which do not have to meet Clean Air Act standards due to grandfathering clauses. On the other hand, a number of comments expressed the concern that Federal restructuring legislation not be used as a vehicle to carry out environmental agendas.

Concern was expressed over the unbundling of natural gas from electricity in the wake of opening electricity markets. It was noted that 98 percent of our public gas systems are served by one pipeline, and while market forces are good, they only work when there is competition. Stakeholders recommended that DOE continue to regulate natural gas supplies to public gas systems and that only local authorities should decide whether to unbundle gas and electric rates.

Electric and gas consumers should have access to adequate, safe, reliable, and efficient energy services at fair and reasonable prices at the lowest long-term cost to society. At the same time, we believe that consumers must have the ability to choose their providers and the services those providers will give.

$$
\text { - Margaret Welsh, NARUC }
$$

Coal. A variety of opinions was expressed regarding the improvement of efficiency and the reduction in environmental impacts of existing coal-fired plants. These opinions ranged from closing the current plants to continuing current operations. Pollution from burning coal was of concern to many of those responding.

Other commenters expressed that additional research and development (R\&D) should be funded to increase the efficiency of the extraction process and reduce environmental effects from coal extraction and consumption. It was suggested that DOE should work to deploy and encourage clean coal technologies abroad, where older technologies are currently used, thereby reducing emissions. Ethanol co-firing was suggested to reduce environmental impacts and greenhouse gas emissions. One individual noted that the CNES should include more discussion concerning better methods of using coal in existing utility and industrial boilers. One viewpoint was expressed that coal can reduce dependence on imported oil. 
The recent focus on global climate change studies has shown that fossil fuels, and especially coal, will continue to be used in the future. And we ask that, given the role of coal, the Department should not just admit or accept but actively champion a vigorous $R \& D$ program in the use of coal in an environmentally friendly manner.

- Richard Bajura,

Director of the National

Research Center for Coal and Energy at the University of West Virginia

Additional comments suggested that an extensive emission trading approach to environmental regulation could reduce emissions of many pollutants.

Natural Gas. Several individuals made comments similar to the following: natural gas "is both abundant and clean burning. Government should do all it possibly can to encourage industrial users as well as citizens to switch from coal and heating oil to natural gas. Producers of natural gas should be encouraged to explore for natural gas" and "[a]uto manufacturers should be encouraged to produce autos which run on natural gas through tax incentives."

Other commenters felt that the United States should "open natural gas markets into cities. The differential between natural gas sold in the marketplace and the price it is sold to the consumer is too high."

A new natural gas technology that recaptured most gases was mentioned. Increased funding for $R \& D$ in alternative energy technologies, diversified fuel sources, and increased environmental constraints was suggested. It was also suggested that natural gas could be used to generate electricity without forming common pollutants through a "green power system."

Hydroelectric. Many respondents addressed the issue of hydroelectric energy. Most comments mentioning hydroelectric power felt that it was a relatively cheap and environmentally friendly form of power. Comments noted that if we are to increase the efficiency of hydropower facilities by
2010, the CNES needs to state that it is done with the involvement of the facility customers.

Some commenters felt that the number of hydroelectric sites should be increased in the United States, while others felt that hydroelectric facilities should not be built because of expense and environmental damage. The issue of licensing and relicensing hydropower facilities was raised by several respondents. Some felt that, due to the unpredictability of licensing and relicensing requirements, it would be difficult to attract the capital to develop new hydro facilities.

Nuclear Energy. Many responses "for" and "against" nuclear energy were received. Several of those responding felt that the draft CNES did not include enough reference to nuclear energy, especially as a long-term goal (see Goal IV). Most scientists and researchers that responded supported nuclear energy and stated that the United States needs to develop a strong nuclear policy in regard to facility life, safety, waste disposal and control, and supply. One commenter urged that the CNES should include more references to the nuclear power industry. Another emphasized that the Federal Government needs to reduce the impediments to the construction of new nuclear powerplants. One suggested that the move to nuclear energy should be a means of building a nuclear-based "hydrogen economy" where nuclear energy is used to dissociate water into hydrogen and oxygen.

One commenter explained that nuclear energy can help meet clean-air commitments and has a lower environmental impact than other energy sources. He recommended that DOE renew its nuclear program. Without this action, nuclear energy's share of U.S. generated electricity will fall from 20 percent today to just 9 percent in 2020 .

Advocates of nuclear energy pressed for additional DOE-funded R\&D of new reactor technology and improvement in the licensing process for current facilities and construction of new nuclear reactors. Nuclear energy was presented as one of the only viable solutions to growing world energy 
demand that would not contribute significantly to environmental problems. It was noted that good results were achieved in DOE's Fuel Recycling Program before funding was cut, and continuation of the program was recommended.

Many comments maintained that there was a contradiction in Administration policy with regard to continued use of existing nuclear facilities. Some observed that while DOE had a legal obligation to accept nuclear waste in January 1998, it had not yet made arrangements to do so, possibly causing several plants to close because they have no remaining storage capacity onsite. It was recommended that DOE develop an interim storage facility.

A concern was expressed that the United States is losing its technical advantage in the nuclear field through declining educational infrastructure. It was recommended that DOE provide funding for the development of the next generation of nuclear facilities.

Several individuals opposed the continuation of nuclear energy. The focus of these comments was related to the dangers imposed on the public by nuclear energy technology. Many commenters, who advocated the phasing out of all nuclear energy technology, cited the nuclear waste issue and stated that subsidies for nuclear energy and fossil energy should be funneled into renewable energy technology R\&D. Concerns about the transport of spent nuclear fuel were also expressed.

Some commenters suggested that exploring other nonnuclear forms of energy and improving the current technologies would be a wise strategy. Nuclear issues are further discussed in Goals III and IV.

Objective 2. Significantly increase energy efficiency in the transportation, industrial, and buildings sectors by 2010.

Most comments related to this objective tended to focus on how the objective would be best achieved. On the regulatory side, several commenters recommended mandating higher mileage ratings for vehicles, setting higher codes and standards (presumably for buildings and consumer appliances), and taxing low-efficiency goods. Suggested market-based strategies included providing incentives to manufacturers, sellers, and consumers of very high-efficiency products, encouraging cogeneration, and promoting, rewarding, or funding efforts to improve efficiency and develop alternative fuels. Commenters felt that the government should be promoting use of mass transit, bicycles, and walking as alternative forms of transportation.

Transportation. DOE was encouraged to continue support for the development of alternative fuels to meet transportation demands, citing goals set under the Energy Policy Act in 1992.

Several individuals suggested that tax incentives for industry and private individuals could be used to accomplish this objective. Specifically, tax benefits could be extended to the auto industry to promote advancements in energy efficiency and pollution control. Commenters also suggested that individuals who carpool to work could receive a tax credit as an incentive to reduce fuel consumption. Individuals also suggested that tax incentives or economicassistance packages could be developed to encourage domestic oil production because it is currently "more economic to purchase foreign oil."

The Administration was criticized for a perceived elimination of the natural gas vehicle program. It was strongly recommended that DOE work to revise the draft CNES to include substitution of nonpetrol fuels for vehicles, expand the Partnership for a New Generation of Vehicles, correct problems with the Federal fleet, deny petition for 80-percent petroleum fuels to be considered alternative, and work with legislators to introduce meaningful incentives for alternative-fuel vehicle development. 
... the Administration's most significant vehicle development program, the Partnership for a New Generation of Vehicles, has announced that it will focus on gasoline and diesel technologies. In fact, natural gas has been dropped from this program, even though the use of natural gas and other alternative fuels and advanced hybrid and fuel-cell vehicles would reduce reliance on imported oil and provide substantially greater environmental benefits.

- Gilbert Sperling,

General Counsel for the

National Gas Vebicle Coalition

It was stated that education is a key issue in changing attitudes about transportation technologies. Another suggestion was made for a higher gasoline tax to pay for more consumer energy education programs. One commenter stated they would "like to see the DOE address the strategic implications of our automobile-based transportation system." The commenter also stated that "it seems ... that a lot of energy usage, monetary expenditures, and environmental damage can be attributed to the operation of personal automobiles and the maintenance and building of our highway system."

One viewpoint was expressed that electric vehicles (EVs) could assist in achieving all of the draft CNES goals. Increased Federal fleet purchases of EVs, increased tax credits for EVs, establishment of financial incentives for EVs, and hybrid vehicle development with grid connectability were all advocated. Several speakers encouraged DOE to work on the development, deployment, and commercialization of electric and other alternative-fuel vehicles.

It was noted that the goals of the Energy Policy Act have not been met. "Our Federal fleet has been sadly lagging in its adoption of alternative-fuel vehicles of all kinds, but most notably the electric and hybrid vehicle." This commenter felt that DOE should have a moral obligation to at least influence other Federal agencies in the use of alternative-fuel vehicles. It was strongly urged that part of the policy statement should be a revitalized effort to bring the
Federal fleet into compliance with the goals of the Energy Policy Act. Specifically noted was a $\$ 90$ million infrastructure development effort established through the Energy Policy Act that has not been appropriately funded.

Alternative Fuels. Individuals from the scientific and research community would be interested in seeing the Federal "[G]overnment come to the forefront in the search for alternative electric energy sources outside of the mainstream arena, and fund those areas that show promise." They also suggested that the United States move away from fossil fuels and into renewable energy. Commenters felt that the government should provide subsidies or incentives for alternative energy sources such as renewable energy.

Others recommended that DOE support the development of biodiesel, asserting that this domestic energy source could reduce the environmental impacts of the transportation sector while increasing domestic farm income. Still others advocated the development of biomass-based ethanol to replace large amounts of fossil fuels. Commenters noted that agricultural fuels such as ethanol and biodiesel should play an important role in the CNES. They also encouraged DOE to resume R\&D support for ethanol. It is believed that the program will only be successful if there is a continuous commitment to alternative fuels and tax credits are assured.

The benefits of fuel cells in meeting U.S. energy needs and not causing environmental damage were mentioned. Increased funding for R\&D programs focused on fuel cells and the use of fuel-cell vehicles in the Federal fleet were suggested.

Industrial and Building Efficiency. Many commenters encouraged increased funding to improve the efficiencies of the current power system and machinery and appliances that use that energy. Others encouraged the development of financial mechanisms that would lower the cost of efficiency improvements, so-called "shared savings." Tax breaks 
for installing solar energy technologies were also suggested.

A comment that occurred repeatedly was to use R\&D and technology to advance efficiencies and to increase funding in the $R \& D$ arena. Stronger DOE R\&D efforts in the area of infrastructure and transportation research were advocated, as was more research into more efficient power transmission and utility company efficiencies. A commenter also noted that the draft CNES needs to define "efficiency." Another person stated that Goal I, Objective 2 in the draft CNES would not be met without "aggressive policies."

The objectives and strategies under your Goal I, Mr. Secretary, primarily emphasize supply technologies. We need tangible strategies for the demand side as well. Under Goal I, Objective 2, I recommend a new strategy to ... "promote and achieve significantly improved end-use energy efficiency." New energy-efficiency standards for our Nation's buildings, appliances, lighting, heating, ventilation, and airconditioning systems, [and] industrial motors would prove highly effective .... I notice that in your energy strategy, you have included standards for full-size automobiles under your Goal I, namely that the cars should achieve an 80-mile-pergallon level by a certain year. And, therefore, we think such an approach could be extended to the appliances and the motors and lighting and all the other areas that I've summarized.

- Ed Meyers,
Commissioner

Commissioner,

In addition to improving energy efficiency in the buildings, transportation, and industrial sectors, many comments suggested using "clean" generation technologies and improving the efficiency of the transmission system through superconductor technology.

\section{Goal II}

Ensure against energy disruptions protecting our economy from external threat of interrupted supplies or infrastructure failure.

Objective 1. Reduce the vulnerability of the U.S. economy to disruptions in oil supply.

Public comment was generally supportive of Objective 1, particularly maintaining and filling the Strategic Petroleum Reserve and guarding against the impact of oil supply disruptions. Several commenters stated that petroleum is a vital energy source for the United States. They explained that it is necessary for DOE to reach out to the petroleum industry in the development of new technologies to mitigate the environmental impacts of petroleum usage and production. Oil producers expressed some dissention. They explained that there are many geographically diverse sources of oil and that it is economically more beneficial to use inexpensive foreign sources than to develop more costly domestic sources.

Disruption Response. One commenter stated that the size and scope of the Strategic Petroleum Reserve should be increased to be "commensurate with current levels of domestic crude oil consumption. At the present time, assets of the Reserve, both storage facilities and stored oil, are being sold to finance the Reserve's operations." The result is that the Reserve is "far less capable of ameliorating distuptions in crude oil imports than it was intended to be when it was originally conceived, and its capacity is continually being eroded, primarily due to budgetary considerations rather than concerns relating to energy policy." A group of independent oil producers recommended that the Strategic Petroleum Reserve be stocked with oil equal to a 90-day supply, 
taking advantage of current low oil prices to buy reserves rather than sell them. One commenter stated that there are reasonable oil disruption scenarios that could last one or two years, and that DOE should develop plans to "provide compensatory mechanisms that will reduce the economic and environmental damage should a disruption occur."

Several offered detailed recommendations in support of Objective 1, including finding technologies to recover oil from lower grade sources, such as heavier crudes and tar sands; R\&D of in-situ microwave retorting of oil-shale; sponsoring relevant R\&D at universities and National Laboratories; continuing to sponsor DOE programs such as the Reservoir Class Demonstration Program and the Advanced Computational Technology Initiative; tax incentives for oil exploration and development; converting the Strategic Petroleum Reserve to private ownership and operation; and the development of an Office of Refining Technologies within DOE to focus on the refining industry. One Member of Congress wrote that the Administration must "lower taxes, reduce regulation, and lower the burden of government on our domestic oil and gas industry."

Expansion of Domestic Oil Supply. One speaker at a public hearing recommended that DOE play a larger role in providing information on oil and gas reserves. He advocated a national repository system for domestic data, explaining that the large oil and gas companies have shifted their focus from domestic to overseas production and that unless DOE steps in, the domestic data they have collected will be lost.

An association of independent oil producers from 33 States stressed that DOE should focus on "preserving the 700 million barrels of annual production from marginal wells" in light of the low current market prices that make much of marginal-well production uneconomic. This association recommended that DOE again review the recommendations of the National Petroleum Council on marginal wells. Another individual commenter suggested that DOE work to create tax credits when crude-oil prices fall to protect this source of domestic production.

Global Concerns. The focus of comments was mostly domestic, as opposed to global. Of those who took a global perspective, a few commenters advocated development of resources and energy trading outside the Middle East, in addition to developing strategic partnerships with friendly Arab nations. Another requested that $\mathrm{DOE}$ inform the public on how the Caspian Sea oil deposits can affect the cost of U.S. energy and that it maintain vigilance on resource developments, disruptions, and economic issues globally.

Representing members of the petroleum industry, two commenters pointed out the impact of unilateral economic sanctions against foreign countries on access to promising exploration areas outside the United States, and its hindrance to American global competitiveness. A major petroleum industry trade group recommended that the CNES recognize the potentially adverse treatment of foreign source income (including the restrictions placed on the use of the foreign tax credit) on limiting the global activity of U.S. firms, as well.

Access to Federal Lands. Opinion on access to Federal lands for resource exploration to boost domestic supply was sharply divided. Several commenters were in favor of increasing access to these resources, while several others were opposed. An example of commenters in favor of opening up these lands:

Access to development of Federal lands in. Alaska and the offshore are critical to reversing the decline in domestic oil production and to increasing the Nation's gas supply. These goals are achievable only if the Federal Government reconsiders its current policy pertaining to access of these areas.

- Independent Petroleum Association of America 
Failure to acknowledge the critical role of Federal lands to future domestic energy supply prospects compromises the seriousness of the draft strategy document.

- American Petroleum Institute

And in support of the opposing position:

We have four major recommendations. First, the CNES should have as an explicit goal decreasing the threats posed by oil and gas exploration and development to America's most sensitive and environmentally important lands and waters. Second, the CNES should do nothing to promote ... development of still pristine Federal lands and waters in the Arctic. Third, the CNES should specifically recommend the permanent protection of the coastal plain of the Arctic National Wildlife Refuge. Fourth, it should acknowledge the importance of the National Petroleum ReserveAlaska as a 'strategic reserve' that should only be tapped in times of a national energy emergency.

\section{- Alaska Wilderness League, Natural Resources Defense Council, N. Alaska Environmental Center, U.S. Public Interest Research Group}

One commenter suggested that DOE open the Arctic National Wildlife Refuge, the National Petroleum Reserve-Alaska, and California offshore oil fields for exploration only to private companies who have a "proven record of responsible operation."

A representative of independent petroleum producers took specific issue with the royalty collection program currently being administered by the Minerals Management Service, supporting legislative proposals to switch to a royalty-in-kind system where producers hand over a portion of production from Federal lands as payment.

Technologies to Limit Growtb in Oil Demand. Several commenters supported the strategy of developing technologies to limit the growth of oil demand. Nuclear fusion was also advocated by several as an additional energy source to complement renewables in limiting growth in oil demand. Some commenters wanted DOE to increase funding for heavy-oil research to prevent further loss of technological knowhow and that funding for coal or light-oil research could be reduced to compensate.

Additional Input. Opinions also differed on means to meet Objective 1 . Some commenters suggested more emphasis on decreasing oil consumption, via use of alternative energy technologies, and less emphasis on increasing production. Another requested that the United States maintain a strong oil and gas industry by reversing policies that currently provide incentives for "major oil companies to move overseas to escape 'punitive' environmental regulations and taxes."

Non-technology solutions to reducing usage were also offered, such as a carbon tax coupled with offsetting reductions in other taxes to make impact revenue neutral, or a tax only on imported oil.

Cautions by some commenters included:

- Balancing an oil production increase with the goal of the Kyoto accords.

- The downside of increasing U.S. production in peacetime is depletion of domestic resources that may be needed in emergencies. One individual suggested a better strategy might be to develop technology for enhanced oil recovery, but leave the oil in the ground until it is needed for emergencies and use foreign supplies before depleting U.S. supplies.

- Goal Il's aim of ensuring against energy disruptions by developing new technologies to increase coal production may conflict with Goal I's effect of reducing the demand for coal and reduce incentives for increased coal production, "despite the fact that it [coal] is the largest fossil fuel reserve in the U.S."

Objective 2. Ensure energy system reliability, flexibility, and emergency response capability.

Commenters were generally positive in their responses to Objective 2 , focusing on 
recommendations for reducing electrical service disruptions through greater system reliability and the importance of distributed power generation.

In the discussion of electricity restructuring (Goal I), many comments were made regarding ways to ensure the reliability of electricity supply.

Reducing Disruption of Service. A research scientist suggested building more redundancy into the energy network and alternative routes for energy when there is a disruption. One company recommended that Objective 2 should include comprehensive measures to address grid reliability management, technological and institutional issues that will result from restructuring, and existing gaps in system reliability.

An individual also stated that Goal II, Objective 2, should add a new Strategy 4: Increase use of renewable energy and energy efficiency in the U.S. to help ensure against energy disruptions. Another suggested that a separate strategy be created for distributed power and cogeneration, emphasizing reliability and market niche applications. This latter strategy would encompass technologies for rapid restoration of power in the event of natural or man-made interruptions.

One commenter cautioned DOE to monitor the effects of electricity deregulation on power availability and reliability and be prepared to impose a "moratorium" on deregulation if it threatens the reliability of the grid.

A hydropower industry group asserted that hydropower, under direct U.S. control and not subject to price and availability fluctuations, offers much in maintaining system reliability and should be considered a priority in the CNES.

The Federal Government has the responsibility to make sure power and energy will be available and uninterrupted through redundancy ...

- Dennis Baker
Distributed Power Generation. Several commenters explained that through utilization of current distributed generation capacity, the United States could meet much of its growing energy needs. One commenter went as far as recommending that the United States phase out dependency on the centralized power grid completely over the next generation or two.

A few individuals suggested instituting policies to restructure cities to reduce urban sprawl. One person, representing a private company, stated that "load control, load shedding, voltage control, and capacitor control are key to electric utilities being able to respond quickly to emergency situations."

A few individuals advocated the use of micro-turbines to serve the distributed generation niche. In addition, the use of hybrid power systems, and especially fuel cell use in these systems, was advocated. Also mentioned was dispersed generation, with backup generators located at sensitive locations such as hospitals, which would create a higher utilization factor, and the use of hard circuitry to avoid high-tech terrorism.

An individual expressed concern that adequate metering and submetering technologies were needed in Federal facilities to provide accurate numbers for efficiency modeling and to verify energy consumption reductions.

Emergency Response Capability. Several commenters also addressed response to emergencies, with suggestions such as the sharing of manpower resources between States in case of emergency and redundaricy built into the energy network so that there are alternative supply routes when disruption occurs in one area. 


\section{Goal III}

Promote energy production and use in ways that respect health and environmental values - improving our health and local, regional, and global environmental quality.

The scope of Goal III - spanning natural gas, oil, nuclear, and renewable energy technologies; deployment of environmentally friendly technologies; and domestic and international greenhouse gas reduction efforts - contributed to the diversity of comments received on this Goal. An attempt is made below to summarize as much as possible the wide variety of viewpoints and subjects the public addressed in their comments.

An overall comment was offered by one utility: promoting energy production and use in the manner stated in Goal III "will result only if all fuels and energy sources are treated equitably and the scientifically based health and environmental standards are applied to all fuels and uses" to prevent skewed application of environmental requirements and disruption of the free market.

\section{Objective 1. Increase domestic energy production in an environmentally re- sponsible manner:}

Most comments were directed toward issues in Objective 1. The concepts of sustainable development and sustainable living were mentioned several times by commenters. Another suggested that stricter enforcement of pollution laws be carried out. One warned that major (energy) construction projects such as dams should not be undertaken unless it can be first proven that alternate sources of energy cannot meet the energy demand. Another commenter recommended that DOE fund long-term scientific research on environmental issues and leave regulation to local authorities.

Mitigation of Environmental Impacts from Energy Production. The specific environmental issues raised included concern over climate change and meeting the challenge set forth for U.S. greenhouse gas emission reductions, and advocacy of environmental regulations which "make sense" for the particular technology and locality. Several speakers raised climate change concerns as they explained why the technology they advocate should play a substantial role in the Nation's energy strategy. Individuals advocated outreach and collaboration with industry in the development and implementation of environmental regulations.

Developing Renewable Electric Generating Technologies. One State's energy commission noted that the renewable energy portfolio standard mentioned in this Objective was a hotly debated issue. Some States have adopted different methods to encourage renewable energy projects, and the commission recommended that the CNES recognize other approaches that advance renewables. A Southern utility holding company noted its opposition to the renewable portfolio standard in the CNES, expressing support for renewables through appropriations and tax credits provided elsewhere in the CNES so electricity producers do not bear the cost burden.

The hydropower industry registered its request that the CNES address hydropower explicitly in Goal III, Objective 1, and lessen the regulatory burdens and costs that are causing renewable energy generated from hydropower to decline.

Developing Renewable Tecbnologies. Many speakers advocated increased R\&D spending for renewable energy technologies. Some individuals thanked DOE for its openness in dealing with industry, while others stated that DOE had not spent enough on renewable energy. One commenter highlighted the role renewables can have globally in meeting energy demand and reducing environmental impacts of energy consumption.

Some commenters supported subsidies to renewable resource energy providers and a reduction in subsidies to fossil-fuel burners. Several commenters advocated increased government support of sustainable renew- 
able energy, including a mandate that all Federal facilities purchase green power.

Concerns over environmental impacts of energy production focused on the need for improving energy efficiency and increasing use of renewable energy technologies. Two individuals discussed three key points: (1) the need to increase funding for renewable energy technologies research, development, and deployment; (2) the need to improve energy efficiency in order to decrease energy intensity and avoid environmental impacts; and (3) the need to phase out older coal-fired powerplants grandfathered under the Clean Air Act. Through adoption of these three measures, the commenters contended that the United States could regain its technological lead in renewable energy and reduce both economic and environmental costs of energy production and consumption. One individual explained that renewable energy technologies will not be able to supply sufficient generation capacity to meet the Nation's growing energy needs.

Several commenters want to expand $R \& D$ and funding in the area of windmills and solar panels for energy production. Commenters would like to see mention in the CNES of solar technologies used in desert regions and particularly Southern states.

Several individuals commented that tax breaks could be given to private citizens for installing energy-saving technologies such as solar panels. One individual was concerned that under current IRS tax laws (Form 3468 ) he could not earn a tax break for installing a solar-electric power system on the roof of his house. He stated that the system is designed to operate for more than 30 years, costs about $\$ 10,000$ to install, and has been working "flawlessly" since installation last year. The commenter felt that current tax laws stifle widespread implementation of technologies such as solar-panel systems. Several commenters stated that installing solar and similar systems would help the United States shift from dependence on foreign energy supplies to a more independent posture.
Wilderness/Indian Land Protection and Protection of Natural Resources. One commenter noted that drilling for oil should not take place in wilderness areas (Arctic National Wildlife Refuge) or roadless areas, while a few promoted drilling in offshore areas near California. One individual stated that public land should be for the public and "not for the profit of large companies." Comments were similar in nature to those received for Goal II (discussed above).

Maintaining a Viable Nuclear Energy Option. With regard to Strategy 4 under Objective 1 , commenters suggested reducing the impediments to construction of new powerplants and allowing "reasonable" licensing extensions for existing plants. Another suggested an evaluation by the National Academy of Engineering of the current safety of nuclear plants to contribute to public confidence.

As in other goals, the lack of mention of fusion as a viable nuclear option in the draft CNES was noted several times by commenters. Another recommended continued R\&D on the liquid metal-cooled breeder reactor.

Several commenters felt that the inability of generators to ship radioactive waste in certain areas or the inability of geologic repositories (that is, Yucca Mountain and the Waste Isolation Pilot Plant) to accept the waste will have a major impact on the U.S. nuclear power industry and research facilities. One commenter recommended that "nuclear waste should be managed ... by an entity entirely accountable to the public whose health is at risk ... but should be entirely paid for by the nuclear industry...."

Objective 2. Accelerate the development and market adoption of environmentally jriendly technologies.

Environmentally Friendly Tecbnologies. A commenter offered that such technologies have value only if driven by "the artificial force of Federal regulation," and that DOE should examine the extent to which 
Objective 2 would meet the quantitative goals for reducing greenhouse gases (presumably under the Kyoto Protocol).

A geothermal energy public-private partnership stressed the inclusion of geothermal in equipment tax credits. On a related note, the partnership expressed a concern that all tax credits may be too high, possibly inciting a boom-bust cycle such as the one witnessed with the solar tax credits of the 1970s.

Similarly, a fuel cell trade association pointed out the benefits of fuel cells in terms of lower carbon dioxide emissions, and their recyclable nature, and requested that $\mathrm{DOE}$ continue funding the Direct Fuel Cell stack technology development and demonstrations in government installations.

Climate Change. Many speakers expressed concern over climate change. One person explained that the market should drive energy choices and that energy markets and the technology focus necessary to meet Kyoto obligations are at odds. Several commenters were opposed to the Kyoto Protocol while many others were in favor of it. Some comments indicated that DOE should focus on developing an energy policy and not on meeting Kyoto Protocol objectives. One suggested that the Protocol was adopted using unproven assumptions and deserves further study.

The electric utility industry was very disturbed by the inequitable treatment which the U.S. was able to negotiate in the Kyoto treaty on climate change. There are a number of technology transfer and international trading and joint implementation programs that would create positive incentives for all parties. The command and control approach, which was negotiated in Kyoto, is unequitable and unworkable. All countries should be active participants in any global climate treaty....

- Texas Utilities Services, Inc.
Other comments dealt with greenhouse gas trading or greenhouse gas reduction in the United States or internationally: through carbon dioxide trading, incentives for new energy technologies that greatly improve local public health, and minimizing local, regional, and global pollution. One State's energy commission recommended that a separate CNES be devoted to developing the science of climate change as a basis for devising sound solutions.

Another commenter supported DOE's efforts to combat climate change and encouraged promotion of voluntary programs, with agencies working as equal partners in identifying and implementing voluntary measures in the public sector as well. $\mathrm{He}$ also recommended that participants in these programs be given credit for early actions. In contrast, a university environmental policy center noted that limitations of voluntary greenhouse gas reduction programs may require mandatory greenhouse gas reductions throughout industries to ensure that all companies are on a level playing field.

Another commenter supported action to mitigate the effects of climate change. In his opinion, only nuclear energy will be able to meet demand without increasing greenhouse gas emissions. One commenter felt the draft CNES placed too much emphasis on greenhouse gas.

Commenters noted that the United States needs to work together with other countries to keep pollution standards high and to form international partnerships. One responder would like to see the United States "make significant contribution to improving energy generation methods for all countries if we want to improve the global environment."

The most important thing government can do is to ensure that technology is freely shared globally.

- Roger Altobelli 
Finally, one commenter felt that Goal III, Objective 2, Strategies 4 and 5 (participating in negotiations with developing countries, and international joint greenhouse gas reduction efforts) might be more appropriately placed in Goal V.

\section{Goal IV}

Expand future energy choices - pursuing continued progress in science and technology to provide future generations with a robust portfolio of clean and reasonably priced energy sources.

Some commenters suggested that costs for R\&D and future energy expansion should be shared by the Federal Government and private industry because industry directly benefits from government research. One commenter felt that the draft CNES should place emphasis on "power production" research rather than just general "scientific" research. A few commenters also felt that research should support efforts in areas of unconventional or nontraditional research; they urged DOE and the Federal Government to be "open-mined" when it considers funding innovative energy projects.

Objective 1. Maintain a strong national knowledge base as the foundation for informed energy decisions, new energy systems, and enabling technologies of the future.

One commenter suggested that Goal IV, Objective 1, Strategy 1 be modified to include the phrase "fusion energy research," after "renewable technologies." Several commenters stated that National Laboratories should be doing high-risk $R \& D$ driven by an industrial advisory committee as has been previously proposed. One person would like to create centers of excellence in the National Laboratories to allow continuity of work - given adequate funding while another would like to see the National Laboratories made more efficient and competitive. One person stated that bureaucracy and huge overheads stifle the Laboratories.
Another commenter suggested that Goal IV, Objective 1, Strategy 3 be modified to read, "Research into the properties of matter in extreme states can feed into future innovation in energy technologies." Several people noted that fusion is important in light of "President Clinton's recent speech at the AAAS meeting in which he highlighted fusion energy as one of the key future benefits of scientific research. Fusion is also an important element of the recent report from the President's Council of Advisors on Science and Technology."

A commenter noted that Objective 1, Strategy 2 should include a review of the status of knowledge about the effects of greenhouse gases by a prestigious body, such as the National Academy of Sciences.

Several commenters stated that Objective 1 should also mention increased basic education for children and the general public. A few commenters stated that Goal IV, Objective 1 , Strategy 4 should mention more universities and private industry to conduct research instead of the National Laboratories that tend to be more costly. In addition, commenters recommended that DOE partner with universities to develop technology and use a streamlined "unsolicited proposal" approach to accelerated R\&D funding.

\section{Objective 2. Develop technologies that expand long-term energy options.}

Commenters were generally supportive of the range of conventional and alternative energy options. Numerous commenters noted that DOE should add "fusion" to Goal IV, Objective 2 as a long-term energy option. Various commenters supported funding more research on fusion and cooperation with Japan and Europe. Commenters realize that fusion is a "cleaner" way of producing electricity than standard fission reactors.

[T] he ability to conduct long-term research in the area of power has been severely hampered at a time where such an effort is needed most.

- Fernando Alvarado 
The fact that the nuclear power system is being downplayed or ignored in this country as compared with other countries that have used it to full advantage has left us behind. Not being able to successfully address waste disposal issues from this power source is not advancing our country's energy independence. Fusion power should be strongly supported as well as any other methods that appear possible. Without broadening our base through research now will cost the next generations that will have to develop these alternatives. The government should be much more proactive on this issue.

Other specific suggestions included increased support for R\&D and a cooperative arrangement with industry and utilities on hydrogen-electric automotive systems. Restoration of funding magnetic fusion, including the International Thermonuclear Experimental Reactor (ITER) and support to the Princeton Plasma Physics Laboratory for Tokamak Fusion Test Reactor upgrades was also mentioned. One commenter suggested high-risk R\&D at National Laboratories driven by industrial advisory committees. A commenter noted that DOE should "develop a broad portfolio" of energy-related R\&D activities. On the dissenting side, one commenter noted that "looks to me that there is an uncritical worship of technology in this proposal, it looks like this document expects miracles from research."

Many speakers and commenters advocated continued or expanded $R \& D$ in a variety of areas. Generally these comments focused on the particular technology an individual advocated. One commenter recommended that DOE look into zero-point energy and referred to a specific technology for harnessing this energy source called the " $N$ " machine. He challenged the Secretary of Energy to fully investigate this technology and let the American public know about it.

Another commenter encouraged DOE to form an office for emerging technologies. The commenter explained that truly new groundbreaking technologies would emerge only when an office is established to engage scientists and researchers who are on the fringe of technology. The commenter explained that much of the research that is currently done in DOE is mainstream and these fringe researchers need an environment in which their work is taken seriously to flourish and publicize their achievements.

\section{Goal V}

Cooperate internationally on global issues - developing the means to address global economic, security, and environmental concerns.

\section{Objective 1. Promote development of} open, competitive international energy markets, and facilitate the adoption of clean, safe, and efficient energy systems.

Of the total number of comments, concern over open and competitive international markets received the fewest. Most of these comments stemmed from the petroleum industry and are captured in the Goal III discussion of embargoes and foreign tax credits.

Other comments included support for the transfer of environmentally sound technologies to the developing world. A representative of the coal industry advocated the export of clean coal technologies to large coal users, like China, to help reduce global levels of pollutants. Similar environmental technology transfer suggestions were made in regard to other fuel sources.

Several commenters suggested that the United States increase international cooperation in research of future energy sources. Other commenters noted that a "World Wide Web" of electricity or a global energy network should be included in the draft CNES. This approach is described as using electricity generated anywhere on the globe, allowing increased access to renewable energy resources, to meet world energy demand. The commenters noted that this approach would allow peak demand for electricity to be spread more evenly due to time-zone differences. 
One speaker suggested that an increase of U.S.-Mexico energy trade (importing oil from Mexico to the United States) would help stem the tide of migration into the American Southwest by providing employment in Mexico.

[D]eveloped and third-world nations [should] commit to a goal of increased energy efficiency and reduced pollution.

\section{- Thomas J. McGeacben}

One individual made the point that in the current atmosphere of environmental concern, environmental policy would become the de facto energy policy if a clear energy policy was not defined. He explained that with the outcome of the Third Conference of the Parties to the United Nations Framework Convention on Climate Change in Kyoto and its significant implications for the energy sector in the United States, it is imperative that DOE define an energy policy which ensures energy security and diversity.

A commenter also stated that the CNES should acknowledge that excess fissile material from the United States and Russia could have an impact on energy resources and the energy market.

Several commenters expressed an interest in seeing DOE cooperate and support international fusion development research. Some of these commenters would like to see the United States build the International Thermonuclear Experimental Reactor (ITER) project for fusion research, preferably in the United States, and felt that building the ITER would assist with fighting global warming by implementing a clean energy source internationally.

Objective 2. Promote foreign regional stability by reducing energy-related environmental risks in areas of U.S. security interest.

Several commenters noted that Goal V, Objective 2 is actually foreign policy and belongs in a State Department document, not a DOE document. One comment cautioned that global cooperation under no circumstances is basis for weakening, waiving, or authorizing exemptions for U.S. Federal, State, or local environmental regulations.

On the environmental security side, commenters recommended International Atomic Energy Agency monitoring of nuclear reactors to insure that no diversion of strategic nuclear materials takes place, ratifying the Kyoto Protocol, and requiring developing countries to abide by regulations set for industrial countries.

\section{General Comments}

\section{Process}

On balance, respondents were pleased with the variety of ways input was solicited for the draft CNES. There were two key criticisms of the process. Several comments indicated that the review period for the draft CNES was too short. In order to provide a careful technical review of the document, a longer review period would be needed. Additional comments were received that indicated that the public should be given more advance notice of hearings.

\section{Document}

Again, comments received about the document were generally favorable. Several comments complimented the concise readability of the document and its "framework" structure. Some comments about the document were negative. These included remarks that the document was light on analysis and specifics. Others characterized the document as blindly optimistic. Several other comments were critical of the document, implying that the reliance on technology to solve grave problems is not realistic. Several comments focused on the need to provide rationale for the specific targets set by the document. Some commenters offered practical advice on technical matters, including the units of measure used for calculations.

\section{Miscellaneous Comments}

The most important energy-related activities the Federal Government should pursue? A wide variety of recommendations was re- 
ceived in response to this question, including: strong support for renewable energy; development of hydrogen-based vehicle technology; reducing environmental regulations so that new generating plants and oil refineries can be built; a national Net Energy Billing policy; increased vehicle gasoline mileage efficiency requirements and nationwide vehicle emission controls; and to go slow on utility deregulation.

Any other comments on the draft CNES? Similar to the previous question, a variety of responses emerged. They included: subsidies to renewable energy providers and reduced subsidies to fossil-fuel consumers; specific targeting of hydrogen as a fuel; loadcontrol switches; pursuing magnetized target fusion (MTF).

Energy Conservation by Adopting a 4Day Work Week. One commenter noted that energy conservation could be accomplished by adopting a 10-hour a day, 4-day work week. Adoption of such a policy saves energy by reducing the electrical power used at the business place, reduces travel to and from work, and reduces frequency of emissions from vehicles.

Commenters also suggested reprioritizing DOE funding to support (1) subsidies for alternative energy sources, (2) basic research on oil recovery and geothermal and field testing of new technologies, (3) $R \& D$ in energy efficiency, (4) energy management projects in Federal agencies, or (5) focusing more of the DOE budget to Goal I and less on defense-related missions.

Commenters stated that alternative technologies should be nonpolluting and affordable. Many comments focused on why a specific technology should be included in the draft CNES. They included advocates of coal, nuclear energy, fuel cells, electric ve- hicles, hydrogen fuels, fusion technologies, distributed generation, the " $N$ " machine, renewable energy technologies, petroleum, and natural gas. Most of these speakers recommended that DOE continue to work collaboratively with industry and fund research efforts for technology development and pollution mitigation.

Several commenters felt that the draft CNES should contain more information related to the demand side of energy. Another commenter felt that the draft CNES was a DOE energy strategy and not a national energy strategy; the commenter also noted that the draft CNES should take into account cooperation with other Federal agencies, including the Environmental Protection Agency, the Departments of Commerce, Housing and Urban Development, Transportation, et al.

Others recommended that the United States provide more support through existing institutions such as the Agency for International Development and grants to other nations, and support the United Nations, the International Energy Agency, the International Atomic Energy Agency, and the Nuclear Energy Agency.

One former assistant secretary of energy stated: "The draft CNES prepared by DOE is inadequate and totally unacceptable. In short, it is irresponsible, it should be considered a 'religious tract' rather than a realistic and enduring plan for our national critical supply of reliable energy at reasonable prices."

Other miscellaneous comments included one person noting that it is difficult to pursue efficiency and equity issues at the same time. Sometimes two programs are needed rather than one. 


\section{Public Comments Database Summary}

\section{Name \\ Greg Ashley \\ Richard Bajura}

Bud Beebe

Steven Bloxham

Dorothy Brownold

Paul Craig

Winifred Detwiler

Stephen Doyle

William Keese

Daniel Kramer

Julee Malinoski-Bell

Tsvi Meidav

Todd OConnor

Alan Pasternak

Gatherine Reheis

Carl Walter

Robert Wichert

David C. Williams

Bertram Wolfe

Dr. Ali

Richard Bajura

Len Bower

Bob Cave

Douglas Durante

Dave Goldstein

Charles Goodman

Burl Haigwood

Adam Kolton

Richard Lawson

John Lichiblau
Organization

Cutler-Hammer

National Research Center for Coal and Energy at

West Virginia University

Sacramento Municipal Utility District

Compressor Control

Private Gitizen, Peace Activist

Sierra Club

Sacramento-Yolo Peace Action

Clean Energy Systems

California Energy

Commission

California Independent Petroleum Association

California Electric Transportation Coalition

TransPacific Geothermal Corporation

Edison Technology Solutions

Lawrence livermore National Laboratory

Western States Petroleum Association (WSPA)

Professional Engineer

Breakthrough Technologies Fuel Cells 2000

Private Citizen

Consultant

Allison Engine Company

Director of the National Research Center for Coal and Energy

American Petroleum Institute

American Public Gas Association

Clean ruels Development coalition

Electric Vehicle Association

Clean fuels Foundation Alaska Wilderness League National Mining Association

Petroleum Industry Foundation
Name

Ed Meyers

Marcus Milling

Eugene F. Peters

Richard Schulze

Ron Simard

Megan Snith

Gilbert Sperling

David Swanson

William Thonas

Thomas Valone

Leroy Watson

Margaret Welsh

Marc Yaker

Maria Abarca

Pete Altman

Don Demoore

Steve Layton

Greg Lucero

Fred McGuire

Cathy Minceberg

Darrell Rangnow

Joe Rubio

Richard Shaw

Tom Smith

John Stauffactier

Bob Stout

Elena Vergara

Rube Williams

Donald Fonteriot

fawn A. Boyd Vigil

Robin Tyner

Charles Deluca

Louis M. Castanier

Knenzli Nino, MD, PhD

T J Gilmartin

Dave A. Mertill
Organization

D.C. Public Service Commission

American Geological Institute

Electric Power Supply Association

Alliance for Sound Nuclear Policy

Nuclear Energy Institute

American Bioenergy Association

National Gas Vehicle Coalition

Edison Electric Institute

Proposition One

Integrity Research Institute

National Biodiesel Board

NARUC

Electricity Consumer Resource Council

AAMA

Sustainable Energy and Economic Development Coalition

Houston Independent School Systems

Equinox Oil Company, National Stripper Well Associations

IBEW

Houston Independent School Systems

Valero Energy

Neighborhood Center, Incorporated

Harris County ARL-CIO

1 Am A Public Citizen

NGC Corporation

Mitchell Energy, Domestic Petroleum Council

Chicano Pamily Center

Texas A\&M University

Private company

U.S. Navy

Private company

University

University

Private company 


\section{Public Comments Database Summary (continued)}

\section{Name}

Gary Lehnertz

Bernie Miller

Sharron Brown

Russell Stein

Donald Fontenot

Jo Ann Coulter Wientjes

Hugh Bahar

Terry R Galloway

George Larson

Matt Bjork

Tony Bartoletti

Mike McMorris

Hamilton T. Hunter

Robert Marsh

Ellis M. LeBouef

Roger Blanchard

Ronald C. Kirkpatrick

Robert Bourque

John Oberlatz

Kevin Eber

Wanda McMurray

Brian Bowman

Richard L. "Scott" McKie

Roger Blanchard

Mark Haynes

Leo D. Campbell

Marge Wood

R. Tomlinson

Ronald C. Kirkpatrick

Ned R. Sauthoff

Tom Smith

Robert Wichert

James C. Liles

Rube B. Williams

Ellen Thomas

Roger Altobelli

Tom Brand

Robert J. Goldston

National Research Center

for Coal and Energy

Fermin Viteri

Edíson Technology

Solutions

Carl E. Walter, P.E.

Fernando L. Alvarado

Donald Beeler

Bard Jackson

Fernando Alvarado

M. J. Plodinec

\section{Organization}

Private company

Private company

Private company

Private company

Private company

Government Contracor

University

Private company

Private company at government site

Lawrence Berkeley

National Laboratory

Lawrence Livermore National Laboratory

Federal government

Retired

Private company

University

University

Non-profit organization Non-profit organization Private company

Private company

University

Tribal Utilities

University

Private company

University

Private company

Private company

University

Non-profit organization

Management Canada

Federal government

University

National Research Center for Coal and Energy

Clean Energy Systems

Edison Technology

Solutions

University

Private company

Federal government

University

University

\section{Name}

W. Heidbrink

Charles Skinner

James E Quinn

Jeffrey Harris

William Becker

Mike I, Green

Peter Smith

Wayne Evelo

George Holz

Nancy Christopher

Dennis Baker

David L. Brimberry

Thomas J McGeachen

W. Kenneth Davis

Michael Powers

Tony Bartoletti

Stephen 0. Dean

Anna R. Mosqueda

Hank

Judy Jordan

Chris Toussaint

Michael E. Frankle

N7THQ

Frederick I. Sparber

Dennis C. Lee

Michael Randall

Ed vall

Greg Swift

Akira Kawasaki

Robert Horst

Marilyn Dinger

Chris Sakata

Christian Steffek

A. Melchizedek

Glen Wurden

David Mikkelsen

Edmund J. Synakowski

David Hammer

Jerry Levine

William B. Harrison, III

Allan Reiman

Mike Beer

Roy little

David Akers

Marlin E. Schmidt

Kathryn Houser, Ph.D.

Integrity Res. Institute

M. Breazeale

David Crockett Williams

Lawrence Goldstein

John Hughes

\section{Organization}

University

University

Retired

University

Federal goverument

Lawrence Berkeley

National Laboratory

Private company

Federal goveriment

Private company

Private company

University

Private company

University

Non-profit organization

Private company

Private company

Private company

Retired

Private company

Private company

Federal government

GO CO national lab

Private company

Private company

Self-employed

Private company

Non-profit organization

Private company

Federal government

University

University

Private company

University

University

University

University

Private company

Private company

Fed. Govt. Contractor

Private company

Integrity Res. Institute

Private company

PIRINC

Utility 


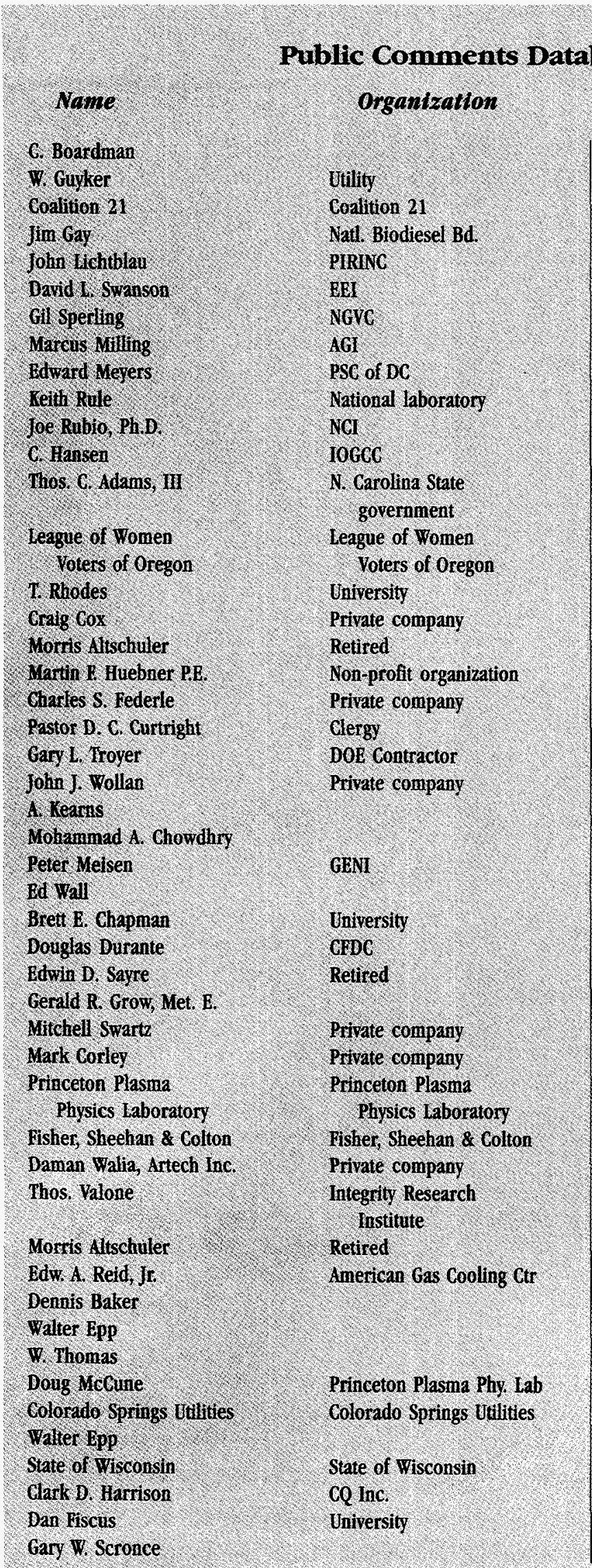

\section{Name}

Dennis Baker

Richard Lawson

Canadian Assoc. of

Petroleun Producers

American Stperconductor

Corp.

State of Hawaii

Natural Rescurces

Defense Council

Union of Concerned

Scientists

Martha Diane Wilhelm

Thos. Dugan

Tsvi Meidav

Bruce Bentley

D. Boneau

Raymond L. Murray

Ronald L. Holton

Daniel S. Rithmond

Brent Schkale

Dan A. Sanchez

Patrick Bailey

Curt MeClymond

Joe Iannucci

Paul Moroz

George Mckee

Natural Gas Supply Assn.

Crr. for Energy \& Envi.

Policy, U. of Del.

New York Mercantile

Exchange

Texas Utilities Services, Inc.

Alaska Wildemess

League, et al.

American Folest \&

Paper Assn, Inc.

Alaska Foruni for Envi.

Responsibility

Independent Petroleum Assn. of America, et al.

Natl. Hydropower Assn.

Dan Kramer

Western Interstate

Energy Board

Assn. of Home Appliance Mfgrs.

Independent Petro Assn. of Mitn. States

California Energy

Commission

B. McGuire
Organization

DOE Contractor

Natl. Mining Assn.

Canadian Assoc. of

Petroleum Producers

American Superconductor Corp.

State of Hawaii

Natural Resources

Defense Council

Union of Concerned

Scientists

Dugan Production Corp

Trans-Pac. Geothermal Corp.

Yates Petroleum Corp.

Uplands Resources Inc.

University

Natural Gas Supply Assn.

Ctr. for Energy \& Envi.

Policy, U. of Del.

New York Mercantile

Exchange

Texas Utilities Services, Inc.

Alaska Wilderness

League, et al.

American Forest \&

Paper Assn., Inc.

Alaska Forum for Envi.

Responsibility

Independent Petroleurn

Assn. of America, et al.

Natl. Hydropower Assn.

Calif. Ind Petrol. Assn.

Western Interstate

Energy Board

Assn. of Home Appliance

Mfgrs.

Independent Petro.

Assn. of Mtn. States

California Energy

Commission

Houston Industries Inc 


\section{Public Comments Database Summary (continued)}

Name

American Petroleum Institute

Ilaska Wilderness

teague, et al.

Natl. Assn of

Regulatory Vtil.

Commissioners

Edison Electric

Institute

Calif. Public ctility

Commission

Natural Gas Vehicle

Coalition

Cinergy Corp.

American Public Power

Power Assn.

Geothermal Energy Assn.

Process Gas Con.

Group \& AST

\section{Orgonizanon}

Name

American Petroleum Instifute

Mlaska Vilderness League, et al.

Natl Assn of Regulatory ItI.

Commissioners

Edison Electric Instizite

Gali. Public Utility Comimission

Natural Gas Vehicle Coalition

Ginergy Corp.

American Public

Power Assn.

Geothermal Energy Assi:

Process Gas Con.

Group \& AISI Joy Mrers Bob hulse

\section{organtation}

CellNet Data Systems, Inc: American Nuclear Society Eron 60. $1 \mathrm{SA}$

Belden \& Blake Corp. Tournal of New Energy Geothermal Heat Punp Consortium

Chas. Goodiman Gary 1. Troyer Mathew 0. Diehl, PE Bertran Wolfe Eugene P Peters Francis C. Pogarty Rick Lewandowski George Freund shelly and Jenny
Southern 60

Elec. Power Supply Assn. 
